\title{
Chronic kidney disease and arrhythmias: conclusions from a Kidney Disease: Improving Global Outcomes (KDIGO) Controversies Conference
}

\author{
Mintu P. Turakhia ${ }^{1}$, Peter J. Blankestijn ${ }^{2}$, Juan-Jesus Carrero ${ }^{3}$, Catherine M. Clase ${ }^{4}$, \\ Rajat Deo ${ }^{5}$, Charles A. Herzog ${ }^{6}$, Scott E. Kasner ${ }^{7}$, Rod S. Passman ${ }^{8}$, \\ Roberto Pecoits-Filho ${ }^{9}$, Holger Reinecke ${ }^{10}$, Gautam R. Shroff ${ }^{11}$, Wojciech Zareba ${ }^{12}$, \\ Michael Cheung ${ }^{13}$, David C. Wheeler ${ }^{14}$, Wolfgang C. Winkelmayer ${ }^{15}$, and \\ Christoph Wanner ${ }^{16 *}$, for Conference Participants ${ }^{\dagger}$
}

\begin{abstract}
${ }^{1}$ Stanford University School of Medicine, Veterans Affairs Palo Alto Health Care System, 3801 Miranda Ave, 111C, Palo Alto, CA 94304, USA; ${ }^{2}$ Department of Nephrology, room F03.220, University Medical Center, P.O. Box 85500, 3508GA Utrecht, The Netherlands; ${ }^{3}$ Department of Medical Epidemiology and Biostatistics, Karolinska Institutet, Nobels väg 12A, Box 281, 17177 Stockholm, Sweden; ${ }^{4}$ Department of Medicine and Department of Health Research Methods, Evidence, and Impact, McMaster University, St. Joseph's Healthcare, Marian Wing, 3rd Floor, M333, 50 Charlton Ave. E, Hamilton, Ontario L8N 4A6, Canada; ${ }^{5}$ Section of Electrophysiology, Division of Cardiovascular Medicine, Perelman School of Medicine at the University of Pennsylvania, 3400 Spruce Street, 9 Founders Cardiology, Philadelphia, 19104 PA, USA; ${ }^{6}$ Division of Cardiology, Department of Medicine, Hennepin County Medical Center and University of Minnesota, Minneapolis, Minnesota and Chronic Disease Research Group, Minneapolis Medical Research Foundation, 914 S. 8th Street, S4.100, Minneapolis, 55404 MN, USA; ${ }^{7}$ Department of Neurology, 3W Gates Bldg. Hospital of the University of Pennsylvania, 3400 Spruce St., Philadelphia, 19104-4283 PA, USA; ${ }^{8}$ Northwestern University Feinberg School of Medicine and the Bluhm Cardiovascular Institute, 201 E. Huron St. Chicago, 60611 IL, USA; ' School of Medicine, Pontificia Universidade Catolica do Paraná, Rua Imaculada Conceição 1155, 80220-901 Curitiba PR, Brazil; ${ }^{10}$ Department für Kardiologie und Angiologie Universitätsklinikum Münster, Albert-Schweitzer-Campus 1, Gebäude A1, 48149 Muenster, Germany; ${ }^{11}$ Division of Cardiology, Hennepin County Medical Center, 701 Park Avenue, Minneapolis, 55415 MN, USA; ${ }^{12}$ Heart Research Follow-up Program, Cardiology Division, University of Rochester Medical Center, Saunders Research Building, 265 Crittenden Blvd. CU 420653, Rochester, 14642 NY, USA; ${ }^{13} \mathrm{KDIGO}$, Avenue Louise 65, Suite 11, 1050 Brussels, Belgium; ${ }^{14}$ Centre for Nephrology, University College London, Rowland Hill Street, London NW3 2PF, UK; ${ }^{15}$ Selzman Institute for Kidney Health, Section of Nephrology, Department of Medicine, Baylor College of Medicine, One Baylor Plaza, ABBR R705, MS: 395, Houston, 77030-3411 TX, USA; and ${ }^{16}$ Division of Nephrology, Department of Medicine, University Hospital of Würzburg, Oberduerrbacherstr. 6 Würzburg D-97080, Germany
\end{abstract}

Received 13 October 2017; revised 18 December 2017; editorial decision 25 January 2018; accepted 27 January 2018; online publish-ahead-of-print 7 March 2018

\section{Introduction}

Patients with chronic kidney disease (CKD) are predisposed to heart rhythm disorders, including atrial fibrillation (AF)/atrial flutter, supraventricular tachycardias, ventricular arrhythmias, and sudden cardiac death (SCD). While treatment options, including drug, device, and procedural therapies, are available, their use in the setting of CKD is complex and limited. Patients with CKD and end-stage kidney disease (ESKD) have historically been under-represented or excluded from randomized trials of arrhythmia treatment strategies, ${ }^{1}$ although this situation is changing. ${ }^{2}$ Cardiovascular society consensus documents have recently identified evidence gaps for treating patients with CKD and heart rhythm disorders. ${ }^{3-7}$

To identify key issues relevant to the optimal prevention, management, and treatment of arrhythmias and their complications in patients with kidney disease, Kidney Disease: Improving Global Outcomes (KDIGO) convened an international, multidisciplinary Controversies Conference in Berlin, Germany, titled CKD and Arrhythmias in October 2016. The conference agenda and discussion questions are available on the KDIGO website (http://kdigo.org/con ferences/ckd-arrhythmias/; 13 February 2018).

The opinions expressed in this article are not necessarily those of the Editors of the European Heart Journal or of the European Society of Cardiology. * Corresponding author. M.P.T. Tel: (650) 858-3932, Fax (650) 852-3473, Email: mintu@stanford.edu; C.W. Tel: +49-931-201 39030, Fax: +49-931-201 639300, Email: Wanner_C@ukw.de

† Other conference participants: Kerstin Amann, Germany; Debasish Banerjee, UK; Nisha Bansal, USA; Giuseppe Boriani, Italy; Jared Bunch, USA; Christopher T. Chan, Canada; David M. Charytan, USA; David Conen, Canada; Allon N. Friedman, USA; Simonetta Genovesi, Italy; Rachel M. Holden, Canada; Andrew A. House, Canada; Michel Jadoul, Belgium; Alan G. Jardine, UK; David W. Johnson, Australia; Min Jun, Australia; Laura Labriola, Belgium; Patrick B. Mark, UK; Peter A. McCullough, USA; Thomas D. Nolin, USA; Tatjana S. Potpara, Serbia; Patrick H. Pun, USA; Antonio L. P. Ribeiro, Brazil; Patrick Rossignol, France; Jenny I. Shen, USA; Manish M. Sood, Canada; Yusuke Tsukamoto, Japan; Angela Yee-Moon Wang, Hong Kong; Matthew R. Weir, USA; James B. Wetmore, USA; Jerzy K. Wranicz, Poland; Hiro Yamasaki, Japan.

(C) The Author(s) 2018. Published by Oxford University Press on behalf of the European Society of Cardiology.

This is an Open Access article distributed under the terms of the Creative Commons Attribution Non-Commercial License (http://creativecommons.org/licenses/by-nc/4.0/), which permits non-commercial re-use, distribution, and reproduction in any medium, provided the original work is properly cited. For commercial re-use, please contact journals.permissions@oup.com 


\section{Atrial fibrillation and stroke in kidney disease}

\section{Epidemiology}

Atrial fibrillation is the most common sustained arrhythmia. ${ }^{8}$ Chronic kidney disease affects $10 \%$ of adults worldwide, ${ }^{9}$ and patients with CKD have an increased burden of AF compared with those without CKD (Supplementary material online, Table S1). The prevalence of AF is high: estimates range from $16 \%$ to $21 \%$ in CKD patients not dependent on dialysis ${ }^{10-12}$ and $15 \%$ to $40 \%$ in patients on dialysis (Supplementary material online, Table S1). ${ }^{13-18}$ Chronic kidney disease and AF share many risk factors, making it difficult to discern the contributions of individual factors to either condition or associated outcomes (Figure 1). For non-dialysis CKD, there seems to be an independent relationship between $C K D$ and the risk of $A F,{ }^{19-25}$ although this association has not been well characterized across the spectrum of estimated glomerular filtration rate (eGFR) or proteinuria. $^{13,14,26,27}$ In the USA, both incidence and prevalence of AF are increasing among haemodialysis patients, ${ }^{27,28}$ which could be because of older age of patients, better ascertainment of AF, and improved survival after vascular events.

\section{Consequences of atrial fibrillation in chronic kidney disease}

The risk of stroke is elevated in non-dialysis ${ }^{29-32}$ and dialysis ${ }^{29,31,33}$ CKD (Supplementary material online, Table S2). Separately, both $C K D$ and $A F$ are risk factors for stroke, but it is currently unknown whether the prognostic significance of CKD markers and AF is independent or interdependent. The association between AF and CKD may be bidirectional; AF may predict new-onset low GFR and proteinuria. ${ }^{21}$ In CKD, the adjusted risk ratios of stroke with AF have varied considerably across CKD subpopulations, ranging from 4.2 in women in the general population, ${ }^{34} 1.3$ in dialysis patients, ${ }^{33,35}$ and with modestly significant $(1.4)^{36}$ and non-significant ${ }^{37}$ associations after kidney transplantation. These differences may be due to greater competing risk of death in more advanced $C K D,{ }^{35}$ a higher baseline risk of stroke in $C K D$ without $A F$, or a higher prevalence of unrecognized AF.

$A F$ increases the risk of incident CKD and progression to ESKD $^{21,38-40}$ (Supplementary material online, Table S3), and increases risk of death in patients with non-dialysis CKD and those on dialysis. ${ }^{13,35,41,42}$ Other outcomes related to $A F$, including heart failure, $\mathrm{SCD}$, and myocardial infarction (MI), require further research. The contribution of AF as a mediator of stroke in CKD, as well as the stroke subtypes observed, requires further study. The competing risk of death in CKD may reduce the importance of the contribution of AF to stroke, which could mitigate the effectiveness of some stroke prevention strategies. $^{35}$

\section{Stroke risk scores}

The predictive value and calibration of the $\mathrm{CHADS}_{2}$ and $\mathrm{CHA}_{2} \mathrm{DS}_{2^{-}}$ VASc stroke prediction scores have only been evaluated in dialysis patients, in which performance appears to be similar to their performance in the general population. ${ }^{16,33,43,44}$

Inclusion of CKD in risk scores to improve stroke prediction has demonstrated variable results. Adding two points for creatinine

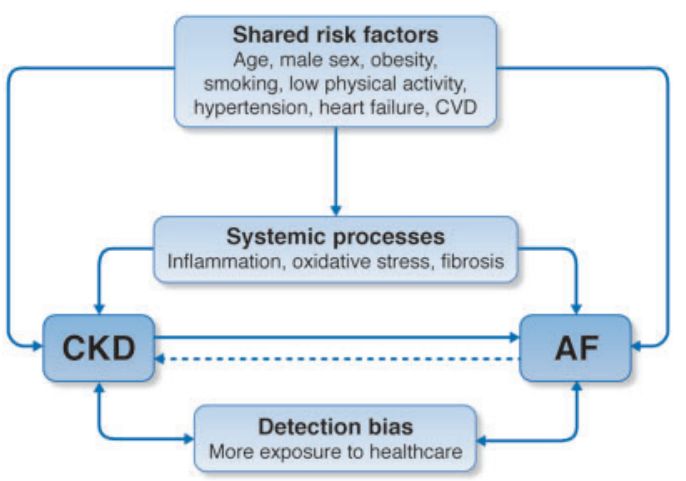

Figure I Relationship between chronic kidney disease and atrial fibrillation: shared risk factors and outcomes. Chronic kidney disease and atrial fibrillation share a number of risk factors and conditions that promote their incidence, possibly via systemic processes such as inflammation, oxidative stress, or fibrosis. It is established that chronic kidney disease increases the incidence of atrial fibrillation and there is some evidence to suggest that atrial fibrillation also increases chronic kidney disease progression. When examining the strength of these associations, we acknowledge the potential impact of detection bias in observational studies where more frequent exposure to healthcare likely prompts more clinical findings in this comorbid population. AF, atrial fibrillation; CKD, chronic kidney disease; CVD, cardiovascular disease.

clearance $<60 \mathrm{~mL} / \mathrm{min}$ to $\mathrm{CHADS}_{2}$ (called $\mathrm{R}_{2} \mathrm{CHADS}_{2}$ ) improved net reclassification index (NRI) but not $\mathrm{C}$-statistic in one large study using external validation ${ }^{30}$ but did not improve NRI or C-statistic in other studies. ${ }^{45,46}$ The ATRIA score, which includes terms for GFR $<45 \mathrm{~mL} / \mathrm{min} / 1.73 \mathrm{~m}^{2}$ and proteinuria, demonstrated improved $\mathrm{NRI}$ and borderline improvement in C-statistic compared with $\mathrm{CHADS}_{2}$ and $\mathrm{CHA}_{2} \mathrm{DS}_{2}$-VASc in external validation, ${ }^{47}$ although NRI may not be clinically meaningulu. ${ }^{48}$ For these reasons and for the potential for categorically recommending oral anticoagulant (OAC) to most patients with CKD without regard to competing risks, $\mathrm{CHA}_{2} \mathrm{DS}_{2}$-VASc remains the most commonly recommended score for risk stratification, ${ }^{5,49}$ and observational data have shown that a treatment threshold of $\mathrm{CHA}_{2} \mathrm{DS}_{2}-\mathrm{VASC} \geq 2$ is associated with $\mathrm{OAC}$ benefit, even in CKD. ${ }^{50}$

\section{Bleeding risk scores}

The HAS-BLED, ORBIT, HEMORR ${ }_{2}$ HAGES, and ATRIA bleeding risk scores all include CKD measures. Although the formal use of these bleeding risk scores has not been recommended by the majority of professional society guidelines, ${ }^{49,51}$ the increased risk of bleeding with and without OAC in CKD is well described and should be considered in clinical decision making.

\section{Stroke prevention and oral anticoagulation}

The pathophysiologic mechanisms responsible for stroke/thromboembolism in patients with CKD and AF are multifactorial and poorly 
Table I Evidence from randomized trial data regarding therapeutic anticoagulation on the basis of kidney function $4,63,64$

\begin{tabular}{|c|c|c|c|c|c|}
\hline $\mathrm{eCrCl}(\mathrm{mL} / \mathrm{min})^{\mathrm{a}}$ & Warfarin & Apixaban $^{\text {b }}$ & Dabigatran & Edoxaban $^{c}$ & Rivaroxaban \\
\hline$>95$ & Adjusted dose (INR 2-3) & $5 \mathrm{mg}$ b.i.d. & $150 \mathrm{mg}$ b.i.d. & $60 \mathrm{mg} \mathrm{QD}^{\mathrm{d}}$ & $20 \mathrm{mg}$ QD \\
\hline $51-95$ & Adjusted dose (INR 2-3) & $5 \mathrm{mg}$ b.i.d. & $150 \mathrm{mg}$ b.i.d. & $60 \mathrm{mg}$ QD & $20 \mathrm{mg}$ QD \\
\hline $31-50$ & Adjusted dose (INR 2-3) & $5 \mathrm{mg}$ b.i.d.(eCrCl cut-off $25 \mathrm{~mL} / \mathrm{min})$ & $150 \mathrm{mg}$ b.i.d. or $110 \mathrm{mg}$ b.i.d. ${ }^{\mathrm{e}}$ & $30 \mathrm{mg}$ QD & $15 \mathrm{mg}$ QD \\
\hline
\end{tabular}

INR, international normalized ratio.

${ }^{a}$ Cockcroft-Gault estimated creatinine clearance $(\mathrm{eCrCl})$

${ }^{\mathrm{b}}$ Apixaban dose modification from $5 \mathrm{mg}$ b.i.d. to $2.5 \mathrm{mg}$ b.i.d. if patient has any two of the following: serum creatinine $\geq 1.5 \mathrm{mg} / \mathrm{dL}$, age $\geq 80 \mathrm{years}$, or body weight $\leq 60 \mathrm{~kg}$.

In the ENGAGE-AF TIMI 48 study, the dose was halved if any of the following: eCrCl of $30-50 \mathrm{~mL} / \mathrm{min}$, body weight $\leq 60 \mathrm{~kg}$, or concomitant use of verapamil or quinidine (potent P-glycoprotein inhibitors).

${ }^{\mathrm{d}}$ This dose has not been approved for use by the US Food and Drug Administration in this category of kidney function.

e In countries where $110 \mathrm{mg}$ b.i.d. is approved, clinicians may prefer this dose after clinical assessment of thromboembolic vs bleeding risk. This dose has not been approved for use by the US Food and Drug Administration.

understood; the precise contribution of cardio-embolic vs. noncardioembolic factors is unclear. Atrial fibrillation may be a direct cause of cardio-embolic stroke, a risk marker of ischaemic stroke including atherothrombotic subtypes, and in rare cases, a consequence of stroke. $^{52}$

\section{Chronic kidney disease patients with estimated creatinine clearance of 30-50 $\mathrm{mL} / \mathrm{min}$}

Pivotal randomized controlled trials (RCTs) have established that direct oral anticoagulants (DOACs) are non-inferior to warfarin among patients with Cockroft-Gault estimated creatinine clearance $(\mathrm{eCrCl})$ of $30-50 \mathrm{~mL} / \mathrm{min}$ (for apixaban, $25-50 \mathrm{~mL} / \mathrm{min}$ ). ${ }^{53-56}$ However, there is insufficient evidence to recommend any one DOAC over any other in this population because no head-to-head trials have directly compared individual DOACs ${ }^{57-62}$ (Table 1). Indirect comparisons are challenging because these trials differed in inclusion criteria and outcome definitions.

Although efficacy (prevention of stroke and systemic embolism) may merely be non-inferior to warfarin, the safety profile of DOACs compared to warfarin does appear to be superior. In all pivotal RCTs, DOACs have been associated with a significant reduction (about $50 \%$ ) in risk of intracranial haemorrhage compared to warfarin. Among patients with eCrCl between 25 and $50 \mathrm{~mL} / \mathrm{min}$, treatment with apixaban and edoxaban resulted in significantly fewer major bleeding events compared with warfarin (Figure 2). ${ }^{63}$ Although these observations do not necessarily indicate the superiority of apixaban and edoxaban relative to other DOACs, it may be helpful to clinicians when treating patients at particularly high-bleeding risk or low time in therapeutic range (TTR) values while receiving warfarin or other vitamin K antagonists (VKAs).

\section{Chronic kidney disease G4, G5, and G5D}

In the absence of trial data, the results from observational studies on the efficacy and safety of anticoagulation for stroke prevention in CKD patients with eCrCl $<30 \mathrm{~mL} / \mathrm{min}$ not on dialysis are conflicting as they are for CKD G5D (Table 2). ${ }^{65}$ There is insufficient highquality evidence to recommend warfarin or other VKAs for prevention of stroke in CKD G5D patients with AF, especially when balancing the significant risks of bleeding, accelerated vascular calcification, and calcific uraemic arteriopathy associated with VKA therapy. ${ }^{66}$ A pooled meta-analysis of 56146 CKD G5D patients with AF from 20 observational cohort studies demonstrated an increase in all-cause bleeding associated with VKA therapy without benefit in reduction of all-cause stroke or ischaemic stroke. ${ }^{65}$ Yet, a wellconducted observational analysis of acute MI patients with AF from the SWEDEHEART registry (2003-2010) found that VKA therapy was associated with a reduced risk of a composite of death, $\mathrm{MI}$, and ischaemic stroke with no increase in bleeding risk across the spectrum of CKD. ${ }^{67}$ The high time in international normalized ratio (INR) TTR in Sweden (>75\%) likely contributed to these findings and has been difficult to replicate in other health systems. ${ }^{68} \mathrm{~A}$ large US health care system analysis found that CKD severity is associated with decreased TTR despite similar INR monitoring intensity. ${ }^{69}$ These findings suggest that TTR is more likely to be poor in CKD and can mediate the increased stroke and bleeding risk in CKD. ${ }^{70}$ VKAs may lead to CKD via repeated subclinical glomerular haemorrhages ${ }^{71}$ or through accelerated tissue or vascular calcification. ${ }^{72}$

The US Food and Drug Administration recently approved mention of the doses of apixaban $5 \mathrm{mg}$ twice daily (with contingent dose modifications) and rivaroxaban $15 \mathrm{mg}$ daily in CKD G5 and G5D (and dabigatran $75 \mathrm{mg}$ orally twice daily for $\mathrm{eCrCl} 15-30 \mathrm{~mL} / \mathrm{min}$ ) on the respective labels based on single/limited dose pharmacokinetic and pharmacodynamic data with no clinical safety data. ${ }^{73-76}$ The conference attendees suggest consideration of the lower dose of apixaban $2.5 \mathrm{mg}$ orally twice daily in CKD G5/G5D to reduce bleeding risk until clinical safety data are available, an approach supported by a recent pharmacokinetic study comparing the two doses. ${ }^{77}$ Recognizing that many CKD patients would likely qualify for a dose reduction to apixaban $2.5 \mathrm{mg}$ orally twice daily anyway (if age $\geq 80$ years or body weight $\leq 60 \mathrm{~kg}$ ), this suggestion honours the 'first do no harm' principle, while acknowledging the lack of clinical efficacy or safety data in this regard (Table 2).

Randomized clinical trials are particularly needed to evaluate VKA use in patients with CKD G5D. A clinical trial evaluating VKAs vs. no oral anticoagulation (AVKDIAL, NCT02886962) is planned. It is not known whether DOACs have an advantage over VKAs in CKD G5D patients with AF. The AXADIA (NCT02933697) and RENAL-AF (NCT02942407) trials of apixaban vs. VKAs in ESKD are enrolling in Germany and USA. 


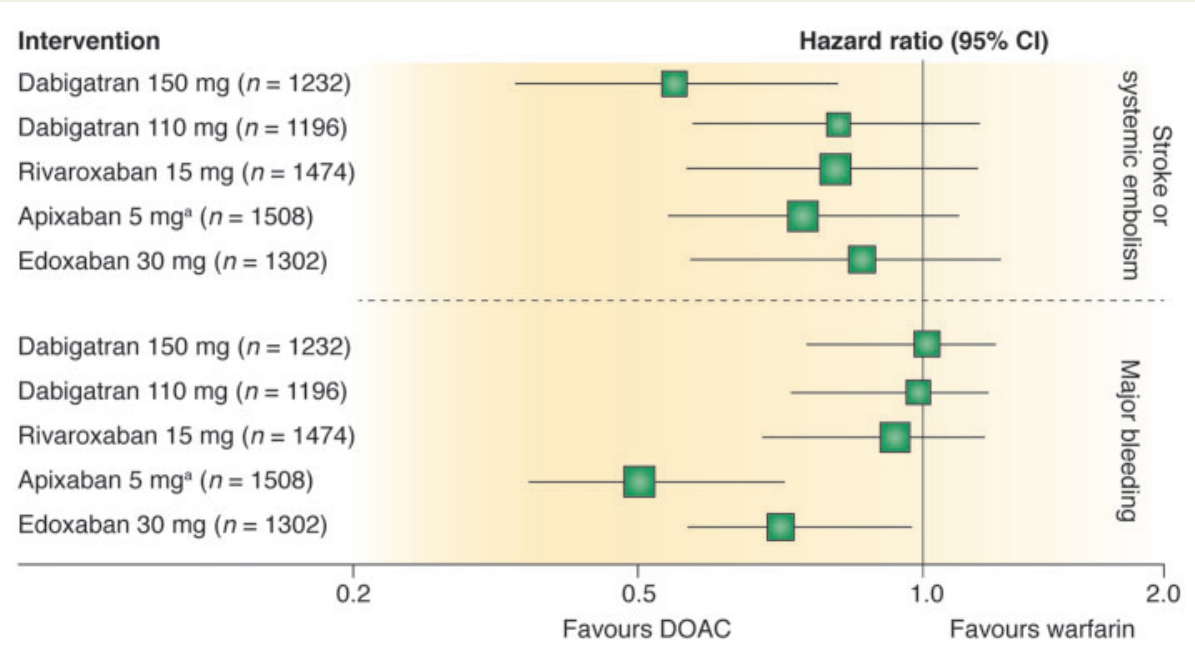

Figure 2 Efficacy and safety of direct oral anticoagulants (DOACs) vs. warfarin in the subgroup of patients with moderate chronic kidney disease from randomized controlled trials in atrial fibrillation. Comparison of hazard ratios and $95 \%$ confidence intervals for primary efficacy and safety outcomes for 150 and $110 \mathrm{mg}$ dabigatran twice daily, $15 \mathrm{mg}$ rivaroxaban once daily, $5 \mathrm{mg}$ apixaban twice daily, and $30 \mathrm{mg}$ edoxaban once daily. Chronic kidney disease was defined as estimated creatinine clearance of 30 to $49 \mathrm{~mL} / \mathrm{min}$ or as 25 to $49 \mathrm{~mL} / \mathrm{min}$ for apixaban. ${ }^{\text {a } A p i x a b a n ~} 2.5 \mathrm{mg}$ twice daily if patient had any two of the following: age $\geq 80$ years, body weight $\leq 60 \mathrm{~kg}$, or serum creatinine $\geq 1.5 \mathrm{mg} / \mathrm{dL}$. Reproduced from Qamar and Bhatt ${ }^{63}$ with permission from the publisher.

Table 2 Chronic kidney disease categories lacking randomized clinical trial data on the utility of anticoagulation ${ }^{4,63,64}$

\begin{tabular}{|c|c|c|c|c|c|}
\hline $\mathrm{eCrCl}(\mathrm{mL} / \mathrm{min})^{\mathrm{a}}$ & Warfarin & Apixaban ${ }^{b}$ & Dabigatran & Edoxaban & Rivaroxaban \\
\hline $15-30$ & $\begin{array}{l}\text { Adjusted dose for INR } \\
2-3 \text { could be } \\
\text { considered }\end{array}$ & $\begin{array}{l}2.5 \text { mg PO b.i.d. could } \\
\text { be considered }\end{array}$ & $\begin{array}{l}\text { Unknown (75 mg PO } \\
\text { b.i.d. })^{c, d}\end{array}$ & $\begin{array}{l}30 \mathrm{mg} \mathrm{QD}^{\mathrm{e}} \text { could be } \\
\text { considered }\end{array}$ & $\begin{array}{l}15 \text { mg QD could be } \\
\text { considered }\end{array}$ \\
\hline$<15$ not on dialysis & $\begin{array}{l}\text { Equipoise based on } \\
\text { observational data } \\
\text { and meta-analysis }\end{array}$ & $\begin{array}{l}\text { Unknown ( } 2.5 \mathrm{mg} \text { PO } \\
\text { b.i.d. })^{c}\end{array}$ & Not recommended & Not recommended & $\begin{array}{l}\text { Unknown (15 mg } \\
\text { QD) }\end{array}$ \\
\hline$<15$ on dialysis & $\begin{array}{c}\text { Equipoise based on } \\
\text { observational data } \\
\text { and meta-analysis }\end{array}$ & $\begin{array}{l}\text { Unknown }(2.5 \mathrm{mg} \text { PO } \\
\text { b.i.d. })^{c}\end{array}$ & Not recommended & Not recommended & $\begin{array}{l}\text { Unknown (15 mg } \\
\text { QD) }\end{array}$ \\
\hline
\end{tabular}

INR, international normalized ratio.

Dosing of direct oral anticoagulants (DOACs) based solely on limited pharmacokinetic and pharmacodynamic data (no randomized efficacy or safety data exist).

${ }^{\mathrm{a}}$ Cockcroft-Gault estimated creatinine clearance.

${ }^{b}$ Apixaban dose needs modification to $2.5 \mathrm{mg}$ b.i.d. if patient has any two of the following: serum creatinine $\geq 1.5 \mathrm{mg} / \mathrm{dL}$, age $\geq 80$ years, or body weight $\leq 60 \mathrm{~kg}$.

'DOAC doses listed in parenthesis are doses that do not currently have any clinical safety or efficacy data. The doses of DOACs apixaban $5 \mathrm{mg}$ b.i.d. ${ }^{\mathrm{b}}$, rivaroxaban $15 \mathrm{mg}$ QD and dabigatran $75 \mathrm{mg}$ b.i.d. are included in the United States Food and Drug Administration approved labelling based on limited dose pharmacokinetic and pharmacodynamics data with no clinical safety data. We suggest consideration of the lower dose of apixaban $2.5 \mathrm{mg}$ PO b.i.d. in CKD G5/G5D to reduce bleeding risk until clinical safety data are available.

dDabigatran $75 \mathrm{mg}$ available only in the USA.

eThe dose was halved if any of the following: estimated $\mathrm{CrCl}$ of $30-50 \mathrm{~mL} / \mathrm{min}$, body weight of $\leq 60 \mathrm{~kg}$, or concomitant use of verapamil or quinidine (potent $\mathrm{P}$-glycoprotein inhibitors).

\section{Pragmatic considerations while managing anticoagulation in chronic kidney disease}

In pivotal RCTs, study eligibility and DOAC dose assignments were based on kidney function as assessed using eCrCl (Cockcroft-Gault). However, in clinical practice, other measures such as eGFR are routinely used. Given the imprecision in measures for estimating kidney function, individualization of DOAC dosing based on either method is reasonable. ${ }^{78-80}$ Important safety concerns, mainly increased fatal or non-fatal bleeding, emerged after the early 'off-label' prescriptions of dabigatran and rivaroxaban in patients with CKD G5D. ${ }^{81-83}$ A recent study of $1473 \mathrm{AF}$ patients with renal indication for dose reduction found that $43 \%$ were potentially overdosed with DOACs, resulting in higher bleeding risk. ${ }^{84}$ These adverse signals suggest the 
Table 3 Recommendations for discontinuation of direct oral anticoagulant prior to elective procedures, according to the risk of bleeding of any specific procedure intervention (low vs. high risk procedures)

\begin{tabular}{|c|c|c|c|c|}
\hline & \multicolumn{2}{|l|}{ Dabigatran } & \multicolumn{2}{|c|}{ Apixaban-Edoxaban-Rivaroxaban } \\
\hline & \multicolumn{4}{|c|}{$\begin{array}{l}\text { No important bleeding risk and/or adequate local haemostasis possible: } \\
\text { perform at trough level (i.e. }>12 \text { or } 24 \mathrm{~h} \text { after last intake) }\end{array}$} \\
\hline & Low risk & High risk & Low risk & High risk \\
\hline $\mathrm{CrCl} \geq 80 \mathrm{~mL} / \mathrm{min}$ & $\geq 24 \mathrm{~h}$ & $\geq 48 \mathrm{~h}$ & $\geq 24 \mathrm{~h}$ & $\geq 48 \mathrm{~h}$ \\
\hline $\mathrm{CrCl} 50-80 \mathrm{~mL} / \mathrm{min}$ & $\geq 36 \mathrm{~h}$ & $\geq \mathbf{7 2 h}$ & $\geq 24 \mathrm{~h}$ & $\geq 48 \mathrm{~h}$ \\
\hline $\mathrm{CrCl} 30-50 \mathrm{~mL} / \mathrm{min}^{\mathrm{a}}$ & $\geq 48 \mathrm{~h}$ & $\geq 96 \mathrm{~h}$ & $\geq 24 \mathrm{~h}$ & $\geq 48 \mathrm{~h}$ \\
\hline $\mathrm{CrCl} 15-30 \mathrm{~mL} / \mathrm{min}^{\mathrm{a}}$ & No official indication & No official indication & $\geq 36 \mathrm{~h}$ & $\geq 48 \mathrm{~h}$ \\
\hline \multirow[t]{2}{*}{$\mathrm{CrCl}<15 \mathrm{~mL} / \mathrm{min}$} & \multicolumn{4}{|c|}{ No official indication for use } \\
\hline & \multicolumn{4}{|c|}{ There is no need for bridging with LMWH/UFH } \\
\hline
\end{tabular}

Bold values deviate from the common stopping rule of $\geq 24 \mathrm{~h}$ low risk, $\geq 48 \mathrm{~h}$ high risk. Low risk is defined as a low frequency of bleeding and/or minor impact of a bleeding. High risk is defined as a high frequency of bleeding and/or important clinical impact. Adapted from Heidbuchel et al. ${ }^{4}$

$\mathrm{CrCl}$, creatinine clearance; DOAC, direct oral anticoagulant; LMWH, low molecular weight heparin; UFH, unfractionated heparin.

aMany of these patients may be on the lower dose of dabigatran ( $110 \mathrm{mg}$ b.i.d.) or apixaban ( $2.5 \mathrm{mg}$ b.i.d.), or have to be on the lower dose of rivaroxaban ( $15 \mathrm{mg} \mathrm{OD})$ or edoxaban (30 mg OD). Dabigatran $110 \mathrm{mg}$ b.i.d. has not been approved for use by the US Food and Drug Administration.

need for systemic measures focused on patient safety to guide clinicians regarding the use of DOACs. ${ }^{85}$

Team-based, multidisciplinary active communication, particularly involving the nephrologist, cardiologist (or cardiac electrophysiologist), primary care physician, and when possible, clinical pharmacist, may be useful to evaluate the risk-benefit of any decision regarding choice of VKA or a DOAC. ${ }^{5,85}$

For CKD patients receiving DOAC therapy, we recommend periodic monitoring of kidney function because decline over time may necessitate dose modification. ${ }^{86}$ There are no data to indicate the optimal frequency of monitoring, but it may be clinically reasonable to assess kidney function every 6 to 12 months, (or at least yearly, consistent with professional society guidelines), ${ }^{5}$ with more or less frequent monitoring as appropriate based on recency of DOAC initiation, CKD severity, and CKD trajectory. For all CKD patients on anticoagulant therapy, annual re-evaluation of treatment goals and discussion of pros and cons of anticoagulant therapy should be considered.

Periprocedural/perioperative management of DOACs is contingent upon individual agents and $\mathrm{eCrCl}$, for which recommended parameters exist (Table 3). ${ }^{4,87}$ For patients with CKD G5D on anticoagulants, strategies to reduce bleeding warrant systematic research but may include minimizing heparin with dialysis, use of citrate locks for catheters, ${ }^{88}$ consideration of prophylaxis for gastrointestinal bleeding when clinically indicated, tight blood pressure control, and discontinuation of concurrent antiplatelet agents if clinically reasonable.

Anticoagulation reversal protocols are well established for warfarin and VKAs. Idarucizumab has been approved for reversing dabigatran, and andexanet alfa has been developed for reversal of anti-Xa agents. Data specific to reversal in CKD patients are limited. ${ }^{89}$

\section{Antiplatelet therapy for stroke prevention for atrial fibrillation in chronic kidney disease}

In a general, mostly non-CKD population, the AVERROES trial of aspirin vs. apixaban was stopped early due to a higher risk of stroke with aspirin but with similar bleeding risk in both groups. ${ }^{90}$ However, there is insufficient evidence to recommend single or dual antiplatelet therapy for prevention of stroke/thromboembolism in AF among patients with CKD G4, G5, or G5D, even when OAC is considered undesirable. Similarly, these patients should not receive concomitant antiplatelet therapy while taking anticoagulants, unless there is a specific secondary indication (e.g. recent coronary stent). The duration of concomitant single or dual antiplatelet therapy in those receiving anticoagulants needs to be minimized and individualized based on clinical factors and type of stent. ${ }^{91}$

\section{Left atrial appendage occlusion in chronic kidney disease}

The left atrial appendage (LAA) is believed to be the site of thrombus formation for most AF-related cardio-embolic strokes. Circulatory exclusion of the LAA represents a non-pharmacological, devicebased therapy for stroke prevention that could conceivably be an option in moderate to high stroke risk in CKD, particularly with contraindications to long-term OAC. Five-year data from two randomized trials of the Watchman ${ }^{\circledR}$ LAA occlusion device demonstrated a reduction in stroke risk comparable to warfarin but with additional reduction in major bleeding. ${ }^{92}$ However, CKD prevalence or severity was not reported and could have been under-represented. The majority of patients receiving the device in trials and in practice are continued on dual- or single-antiplatelet drug therapy, which may be associated with higher bleeding risk in CKD. Moreover, enrolled subjects were without contraindications and hence randomized. Registry data of the Amplatzer Cardiac Plug, a similar device, has shown comparable procedural safety in CKD vs. normal kidney function. ${ }^{93} \mathrm{~A}$ randomized trial of LAA occlusion vs. VKAs in CKD Stages 4 and 5 (CKD G4 and G5) is ongoing (https://clinicaltrials.gov/ct2/show/ NCT02039167; 13 February 2018).

\section{Rate vs. rhythm control of atrial fibrillation}

Indications for a rhythm control strategy in CKD patients mirror those in the general population. The major evidence-based indication 


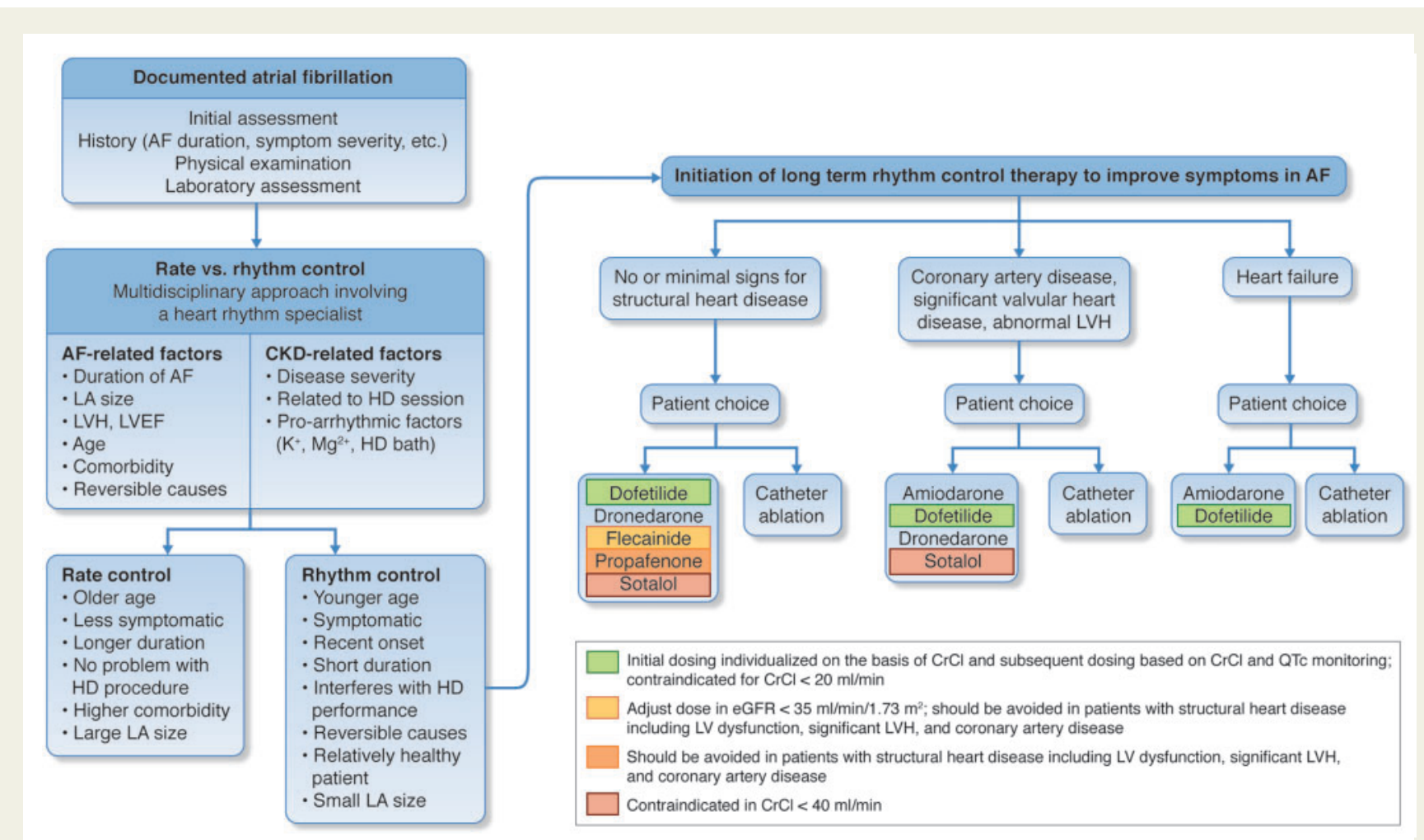

Figure 3 Algorithm for decision-making about rate vs. rhythm control in chronic kidney disease. Especially since chronic kidney disease patients show a lot of specific characteristics regarding history, comorbidities and personal preferences, in each patient an individualized decision should be made. Many aspects should be taken into account: the duration of atrial fibrillation, the symptom severity, renal clearance (risk of toxicity, dialyzability), and potential contraindications for antiarrhythmic drugs due to structural heart disease, which is very frequent in these patients (such as left ventricular hypertrophy, reduced ejection fraction, obstructive coronary artery disease). Moreover, proarrhythmic effects (such as QT prolongation) may be pronounced because of electrolyte imbalances in chronic kidney disease. The figure suggests an algorithm presenting the most relevant criteria that should be incorporated into a multidisciplinary decision-making process, including the treating nephrologist, a heart rhythm specialist, and eventually also physicians of other disciplines. Of note, regardless of which strategy is chosen, oral anticoagulation should always be administered in early stages of chronic kidney disease and at least be considered in advanced stages of chronic kidney disease (see section on Stroke prevention and oral anticoagulation). AF, atrial fibrillation; CKD, chronic kidney disease; $E F$, ejection fraction; eGFR, estimated glomerular filtration rate; HD, haemodialysis; LA, left atrial; LVEF, left ventricular ejection fraction; LVH, left ventricular hypertrophy. Adapted in part from Kirchhof et al. ${ }^{5}$

for a rhythm-control strategy for AF is symptom reduction, although many patients are asymptomatic. ${ }^{5,49}$ Older randomized trials have demonstrated that rhythm and rate control strategies are equivalent in terms of their effects on risks of heart failure, stroke, and survival. $^{94-97}$ Retrospective analyses have suggested rhythm control with ablation provides superior outcomes, but the evidence is limited. Regardless of which strategy is pursued, anticoagulation should also be continued based on stroke risk (as indicated by the $\mathrm{CHADS}_{2}$ or $\mathrm{CHA}_{2} \mathrm{DS}_{2}$-VASc score), unless otherwise contraindicated. Additional factors that may favour attempts at rhythm control include difficulty in achieving adequate rate control, younger patient age, tachycardia-mediated cardiomyopathy, first episode of AF, AF that is precipitated by an acute illness or surgery, and patient preference (Figure 3). ${ }^{5,49}$ Haemodialysis patients with haemodynamic instability due to AF during dialysis sessions may benefit from rhythm control. The impact of its treatment on outcome is unknown. ${ }^{98}$ Patients without clear indications for a rhythm control strategy should default to rate control. In the general population of patients with permanent $A F$ and preserved ejection fraction, lenient rate control (i.e. resting heart rate $<110$ beats per minute) has been shown to be equivalent to a strict rate control for a combined endpoint including stroke, heart failure, death, and need for pacemaker or implantable cardioverter-defibrillator (ICD). ${ }^{99}$

No RCTs have specifically compared rate vs. rhythm control or strict vs. lenient rate control in patients with CKD or ESKD. In a post hoc analysis of the GUSTO III trial, treatment with a rhythm or rate control strategy did not significantly impact short- or long-term mortality regardless of kidney disease status. ${ }^{100}$

\section{Considerations about rate control}

Special considerations in CKD include alterations in symptomatology and a potentially increased propensity to develop tachycardiamediated cardiomyopathy, given the prevalence of structural heart disease. Moreover, the pharmacokinetic and dialyzability of rate control agents in CKD need to be considered (Table 4). When the ventricular rate cannot be controlled with medical therapies alone, atrioventricular nodal ablation and pacemaker implantation can be considered. However, the high rates of complications from transvenous devices in haemodialysis patients should enter into the decision- 
Table 4 Characteristics of antiarrhythmic drugs for rate control in chronic kidney disease

\begin{tabular}{|c|c|c|c|c|}
\hline Drug & $\begin{array}{l}\text { Protein } \\
\text { binding }\end{array}$ & Elimination & Dialyzable & Dosing in CKD \\
\hline Atenolol & $5 \%$ & Excreted unchanged in urine & Yes & Dose may need to be reduced \\
\hline Propranolol & $>90 \%$ & Hepatic metabolism & No & $\begin{array}{l}\text { Serum creatinine may increase, but no dose adjust- } \\
\text { ment is needed }\end{array}$ \\
\hline Bisoprolol & $30 \%$ & $50 \%$ excreted unchanged in urine & No & Dose may need to be reduced in advanced CKD \\
\hline Metoprolol & $12 \%$ & Hepatic metabolism & Yes & No dosage reduction needed \\
\hline Carvedilol & $99 \%$ & Mainly biliary and $16 \%$ urinary & No & $\begin{array}{l}\text { Specific guidelines for dosage adjustments in renal } \\
\text { impairment are not available; it appears no } \\
\text { dosage adjustments are needed }\end{array}$ \\
\hline Labetalol & $50 \%$ & $\begin{array}{l}\text { Inactive metabolites excreted in urine } \\
\text { (5\% unchanged) and bile }\end{array}$ & No & Dose reduction recommended in the elderly \\
\hline Verapamil & $90 \%$ & $70 \%$ is excreted in the urine and $16 \%$ in faeces & No & $\begin{array}{l}\text { Dose reduction by } 20-25 \% \text { if } \mathrm{CrCl}<10 \mathrm{~mL} / \mathrm{min} \text {, } \\
\text { not cleared by haemodialysis }\end{array}$ \\
\hline Diltiazem & $70-80 \%$ & $2-4 \%$ unchanged drug excreted in the urine & No & Use with caution \\
\hline Digoxin & $20-30 \%$ & $\begin{array}{l}\text { Main route of elimination is renal (closely } \\
\text { correlated with the GFR) with } 25-28 \% \text { of } \\
\text { elimination by non-renal routes }\end{array}$ & No & $\begin{array}{l}\text { Dosage adaptation is required, monitoring of serum } \\
\text { digoxin levels }\end{array}$ \\
\hline
\end{tabular}

making process. ${ }^{107}$ Whether leadless pacemakers have a role in this situation remains to be determined.

\section{Considerations about rhythm control}

Direct current cardioversion (DCCV) is the most commonly used method of rhythm restoration in patients with persistent AF. The success rate of DCCV been reported to be similar regardless of kidney function. ${ }^{108}$ However, the risk of recurrence of $A F$ increases as eGFR decreases, although patients with mild-to-moderate CKD in whom sinus rhythm is maintained may experience an improvement in kidney function. ${ }^{109}$ Direct current cardioversion alone is generally insufficient to maintain normal sinus rhythm, and long-term antiarrhythmic drugs or ablation are necessary for rhythm control.

The use of antiarrhythmic drugs for rhythm control is limited in patients with CKD because of issues with renal clearance and proarrhythmic risks in individuals with structural heart disease (Table 5). Amiodarone, the antiarrhythmic drug most commonly used to treat $A F$, does not appear to negatively affect survival, regardless of eGFR function, even in ESKD. ${ }^{111}$ Whether CKD patients treated with amiodarone are at higher risk for organ toxicity is unknown.

Catheter ablation is more effective than antiarrhythmic drugs alone for maintenance of sinus rhythm. The safety and efficacy of AF ablation in CKD was evaluated in 21091 ablations, in which 1593 cases (7.6\%) had CKD and 60 were on dialysis. ${ }^{112}$ Among patients selected for AF ablation, those with and without CKD had similar rates of post-procedural complications and subsequent AF hospitalization, DCCV, and repeat ablation, although the patients with CKD were more likely to be re-admitted for heart failure. A meta-analysis of four studies of pulmonary vein isolation using radiofrequency ablation in patients with CKD showed a nearly two-fold increased risk of AF recurrence, possibly as a result of larger pre-ablation left atrial volumes, which may serve as a marker for non-pulmonary vein triggers of $A F .^{113}$ In a study of CKD patients undergoing cryoballoon ablation, patients with CKD G3 had significantly higher rates of AF recurrence compared with those with CKD G1 and G2. ${ }^{114}$ No cases of contrastinduced nephropathy were reported. In general, sinus rhythm maintenance via ablation is associated with improved eGFR, while ablation failure is associated with eGFR decline. ${ }^{115}$

Atrial fibrillation ablation may potentially provide survival benefit in the setting of reduced left ventricular ejection fraction (LVEF) and heart failure. A randomized trial of catheter ablation compared to usual care in AF and LVEF $<35 \%$ recently reported an improvement in survival associated with ablation ${ }^{116,117}$ (https://clinicaltrials.gov/ct2/ show/NCT00643188; 13 February 2018).

In contrast to atrial fibrillation, radiofrequency ablation for rhythm control of atrial flutter should be considered as first-line therapy in CKD patients given the high success and low complication rates of ablation. Patients with CKD are at higher risk of long-term AF following ablation of atrial flutter and may require long-term monitoring to survey for $A F$ recurrences if a withdrawal of anticoagulation is being considered. ${ }^{118}$

\section{Lifestyle modifications}

Weight loss and exercise, can reduce the burden of AF in the general population, ${ }^{119,120}$ as does treatment for obstructive sleep apnoea. ${ }^{121,122}$ Patients on haemodialysis have a four-fold higher risk of sleep-disordered breathing compared with control patients matched for age, gender, race, and body mass index. ${ }^{123,124}$ However, in a claims-based study of older patients in the USA, 
Table 5 Characteristics of antiarrhythmic drugs for maintaining sinus rhythm in chronic kidney disease

\begin{tabular}{|c|c|c|c|c|c|}
\hline Drug & $\begin{array}{l}\text { Protein } \\
\text { binding }\end{array}$ & Elimination & Dialyzable & Dosing in CKD & $\begin{array}{l}\text { Special considerations } \\
\text { in CKD }\end{array}$ \\
\hline Flecainide & $40 \%$ & $\begin{array}{l}35 \% \text { excreted unchanged in } \\
\text { urine }\end{array}$ & No & $\begin{array}{l}\text { Dose reduction if eGFR } \\
<35 \mathrm{~mL} / \mathrm{min} / 1.73 \mathrm{~m}^{2}\end{array}$ & $\begin{array}{l}\text { Do not use if significant } \\
\text { structural heart disease } \\
\text { present }\end{array}$ \\
\hline Propafenone & $95 \%$ & $\begin{array}{l}38-50 \% \text { excreted in urine } \\
\text { as active metabolites } \\
\text { (1\% unchanged) }\end{array}$ & No & $\begin{array}{l}\text { Careful monitoring recom- } \\
\text { mended (in hospital initi- } \\
\text { ation if advanced CKD) }\end{array}$ & $\begin{array}{l}\text { Do not use if significant } \\
\text { structural heart disease } \\
\text { present }\end{array}$ \\
\hline Amiodarone & $99 \%$ & No renal elimination & No & $\begin{array}{l}\text { No dosage requirements; not } \\
\text { dialyzable; many drug-to- } \\
\text { drug interactions }\end{array}$ & \\
\hline Dronedarone & $98 \%$ & $6 \%$ excreted in urine & Unlikely to be dialyzed & $\begin{array}{l}\text { No dosage adaptation } \\
\text { required in kidney failure }\end{array}$ & $\begin{array}{l}\text { Do not use if } \mathrm{EF}<35 \% \text { or } \\
\text { recent } \mathrm{CHF}\end{array}$ \\
\hline Dofetilide & $60-70 \%$ & $\begin{array}{l}80 \% \text { renally excreted, as un- } \\
\text { changed ( } 80 \%) \text { or inactive/ } \\
\text { minimally active } \\
\text { metabolites }\end{array}$ & Unknown & $\begin{array}{l}\text { Initial dose individualized on } \\
\text { the basis of } \mathrm{CrCl} \text { and sub- } \\
\text { sequent dosing based on } \\
\mathrm{CrCl} \text { and QTc monitoring }\end{array}$ & $\begin{array}{l}\text { Contraindicated for } \mathrm{CrCl} \\
<20 \mathrm{~mL} / \mathrm{min}\end{array}$ \\
\hline Sotalol & $\begin{array}{l}\text { Not protein } \\
\text { bound }\end{array}$ & $\begin{array}{l}70 \% \text { excreted unchanged in } \\
\text { urine }\end{array}$ & $\begin{array}{l}\text { Yes_-give maintenance } \\
\text { dose after } \\
\text { dialysis or supplement } \\
\text { with } 80 \text { mg after HD }\end{array}$ & $\begin{array}{l}\text { A relative contraindication in } \\
\text { view of the risk of proar- } \\
\text { rhythmic effects; in rare } \\
\text { and selected cases-dose } \\
\text { to be halved or reduced to } \\
\text { one quarter in CKD }\end{array}$ & $\begin{array}{l}\text { A relative contraindication in } \\
\text { view of the risk of proar- } \\
\text { rhythmic effects }\end{array}$ \\
\hline
\end{tabular}

CHF, congestive heart failure; CKD, chronic kidney disease; $\mathrm{CrCl}$, creatinine clearance; EF, ejection fraction; eGFR, estimated glomerular filtration rate; HD, haemodialysis. Modified from Potpara et al. ${ }^{101}$

Propafenone elimination data from Drugbank.ca. ${ }^{110}$

Dialyzability data from Frishman. ${ }^{106}$

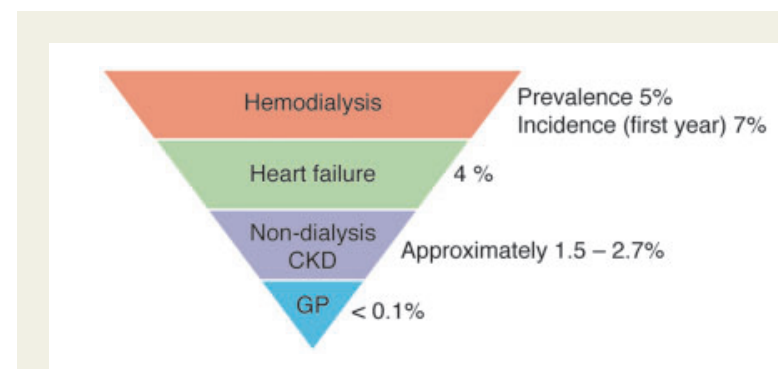

Figure 4 Annual rates of sudden cardiac death. CKD, chronic kidney disease; GP, general population.

sleep-disordered breathing in haemodialysis patients was not associated with $\mathrm{AF}^{125}$

\section{Prevention of sudden cardiac death}

\section{Incidence and aetiology of sudden cardiac death in chronic kidney disease and end-stage kidney disease populations}

There is an increased risk of SCD in CKD (Supplementary material online, Table S4). ${ }^{126-132}$ SCD accounts for $25-29 \%$ of all-cause mortality in haemodialysis patients and around $30-35 \%$ of all-cause mortality in patients initiating dialysis. ${ }^{133-139}$ Recent data indicate that although all-cause mortality rates in haemodialysis patients have been decreasing, the rates of SCD remain the same, indicative of an increased proportion of patients dying from SCD. ${ }^{140}$ Risk of all-cause mortality is substantially higher in dialysis (15-20\% at 1 year) than in heart failure or post-infarction patients (3-8\% at 1 year). ${ }^{140-143}$ Annual risk of SCD is higher in haemodialysis patients in comparison to other patient populations (Figure 4): $5-7 \%$ in haemodialysis patients, $4 \%$ in heart failure patients, and $1.5-2.7 \%$ in non-dialysis patients. The annual rates in non-dialysis patients are comparable to that of post-infarction patients. ${ }^{126,132,136,140,142-144}$ Nephrologists should be encouraged and educated to discuss risks and potential treatment options with patients, and enhance participation in clinical trials.

There is a significant gap of knowledge in the understanding of electrical and haemodynamic mechanisms underlying SCD (Figure 5). In a retrospective study of haemodialysis patients who were prescribed a wearable cardioverter defibrillator, $80 \%$ of cardiac arrests were recorded as ventricular tachyarrhythmias (ventricular tachycardia or ventricular fibrillation) compared to $20 \%$ bradyarrhythmias. ${ }^{145}$ In a recent study with continuous electrocardiogram (ECG) monitoring, bradyarrhythmias and asystole, rather than ventricular tachyarrhythmias, were important determinants of SCD in ESKD patients. ${ }^{146}$

The definitions of sudden death and SCD in ESKD patients need to be refined. The unexpected nature of sudden death needs to be 


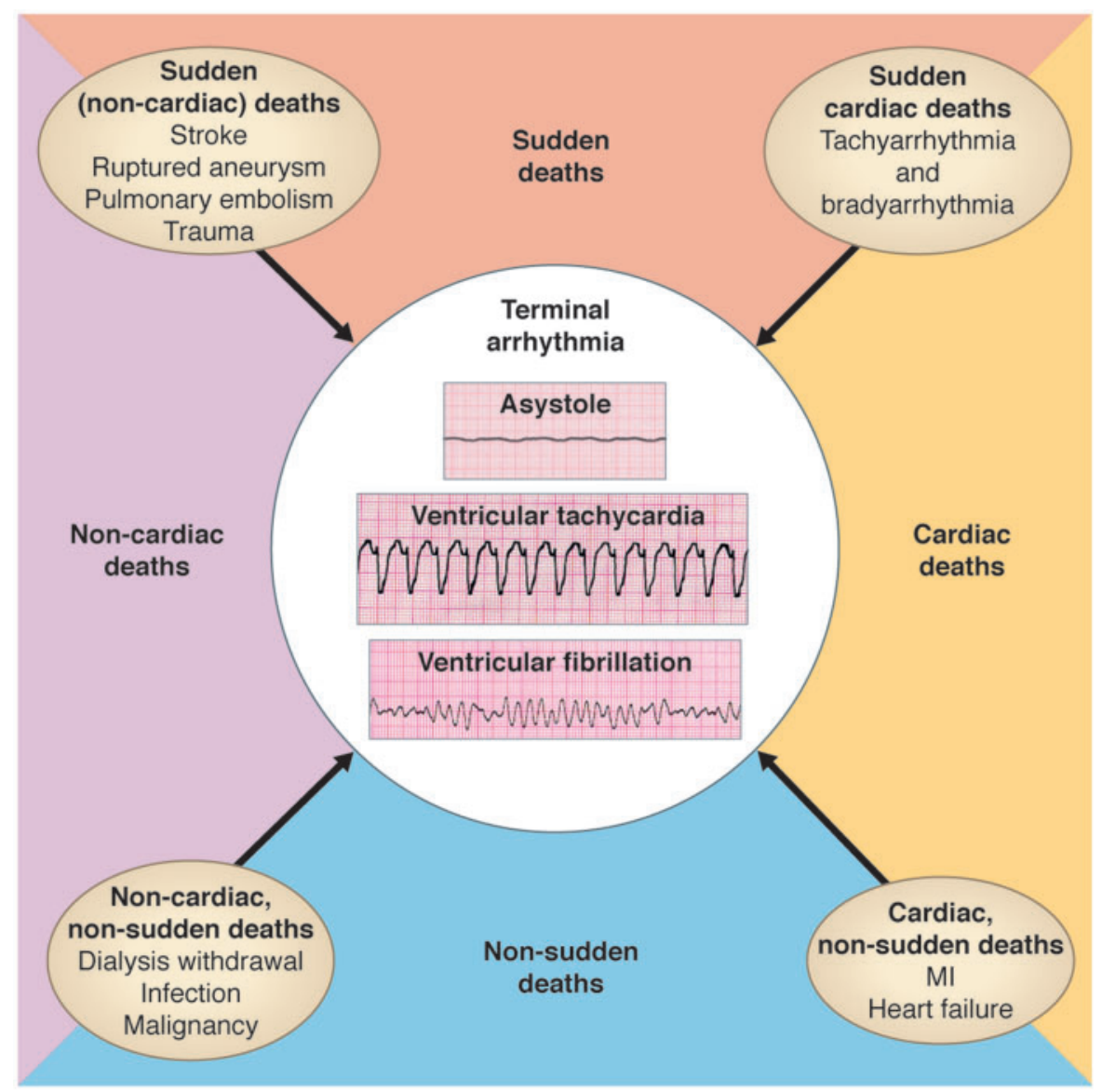

Figure 5 Mechanisms of death in chronic kidney disease patients.

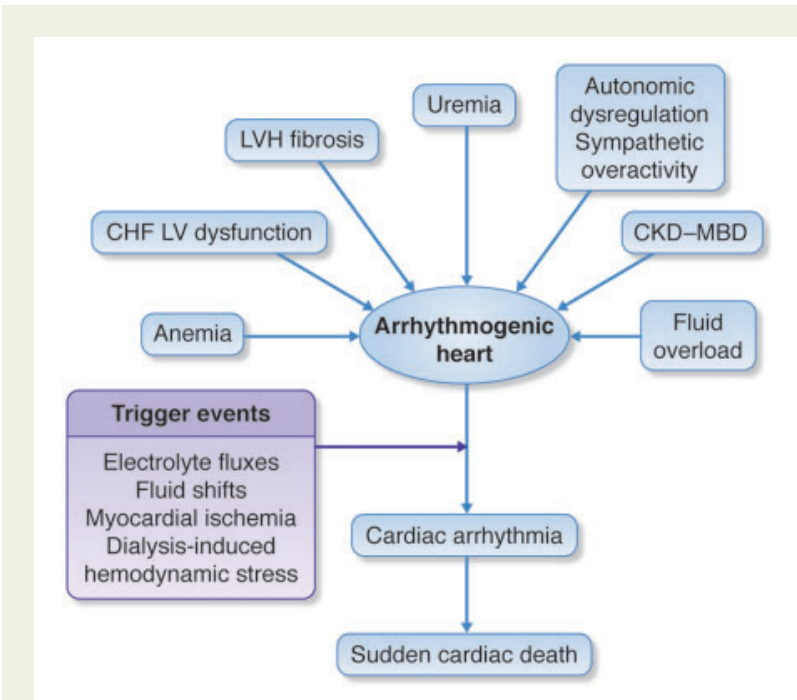

Figure 6 Potential predisposing factors of sudden cardiac death. $\mathrm{CHF}$, congestive heart failure; CKD-MBD, chronic kidney diseasemineral and bone disorders; LV, left ventricular; LVH, left ventricular hypertrophy. emphasized to avoid misclassifications. Supplementary material online, Table S5 proposes definitions of sudden death, SCD, and aborted cardiac arrest pertinent for ESKD patients.

\section{Risk factors for sudden cardiac death in chronic kidney disease and end-stage kidney disease patients}

The mechanisms of SCD in CKD and ESKD incorporate the longstanding, pathophysiologic abnormalities that predispose to the arrhythmogenic conditions and the triggering mechanisms which precipitate sudden cardiac arrhythmia (Figure 6).

The roles of myocardial ischaemia, electrolyte, and volume shifts with haemodynamic instability, left ventricular hypertrophy, fibrosis and dysfunction, as well as autonomic dysregulation and sympathetic overactivity in the pathway leading to SCD, will all need to be further evaluated.

Risk factors predisposing to SCD have been identified in ESKD patients (Supplementary material online, Table S6) and usually their combinations contribute to SCD. ${ }^{136,147}$ Future studies need to determine whether SCD-specific risk factors could be recognized. ${ }^{7}$ Since it is difficult to identify SCD-specific risk factors in patients without ESKD, it might be that just cardiac death-specific risk factors will 
suffice to evaluate life-saving interventions in ESKD patients. ${ }^{148}$ The primary focus should be on modifiable risk factors which could be targets for intervention (Supplementary material online, Table S6). ${ }^{147}$

The role of modifiable biomarkers (defined as laboratory tests that are measurable in blood, urine, or saliva) has been investigated in risk stratification of CKD and ESKD but requires further studies. ${ }^{149}$ Troponins and brain natriuretic peptides could have an additive value and should be further explored to assess their role in a comprehensive risk assessment for SCD. ${ }^{150-153}$

There are very limited data regarding the prognostic significance of incidentally detected arrhythmias in CKD and ESKD. Identification of episodes of non-sustained ventricular tachycardia, frequent premature ventricular complexes, bradyarrhythmias and pauses may be useful in identifying patients at risk of SCD. ${ }^{154}$ Ongoing and upcoming studies with long-term ECG monitoring devices (implantable loop recorders or external ECG monitoring patches worn over a few days to weeks) will provide data regarding incidence and prognostic significance of these arrhythmias.

Syncope is yet another important and not infrequent event observed in CKD and ESKD patients, but its prognostic significance is uncertain. ${ }^{155}$ Transient loss of consciousness due to hypovolaemia or hypotension should be classified as syncope and considered as such for prognostication and treatment.

\section{The role of defibrillator therapies for primary and secondary prevention of sudden cardiac death in end-stage kidney disease}

Data regarding secondary prevention ICD therapy indicate some benefits but further studies are needed to assess longer-term risk vs. benefit that account for competing risks of death. ${ }^{7,156,157}$ Primary prevention ICD therapy is indicated in patients with $L V E F \leq 35 \%$ although data on benefits of primary prevention ICD therapy in patients with $L V E F \leq 35 \%$ and advanced CKD are not encouraging, ${ }^{158}$ as compromised by competing morbidity and mortality and high risk of complications. Patients with LVEF $\leq 35 \%$ account for $10-15 \%$ of dialysis patients, ${ }^{159,160}$ but no data exist for the majority of dialysis patients with LVEF $>35 \%$. Available data seem to suggest that the benefit of ICDs decreases with declining GFRs, in relationship to competing risks of comorbidity and mortality and high risk of complications. ${ }^{129,161}$ Studies with subcutaneous defibrillators, which do not have transvenous hardware, are needed since this approach might be associated with fewer and less severe complications, such as infection. ${ }^{162}$ Wearable cardioverter defibrillators may provide protection for a limited high-risk period. ${ }^{145}$ Further assessment of pacing devices for bradyarrhythmias (including leadless pacemakers) is needed. ${ }^{146}$

\section{Potassium homeostasis and handling in chronic kidney disease and dialysis}

\section{Electrolyte abnormalities and risk for cardiovascular or arrhythmic events}

Although definitive evidence for causality is lacking, both hyperkalaemia and hypokalaemia have been associated with higher risk of all-cause and cardiovascular mortality in patients with ESKD. In patients on haemodialysis, when pre-dialysis serum potassium values (i.e. potassium values on blood drawn at the start of the haemodialysis procedure, in keeping with clinical practice) rise or fall away from $5 \mathrm{mEq} / \mathrm{L}$, the risk for sudden cardiac arrest increases. ${ }^{147}$ Among incident haemodialysis patients, higher mortality and hospitalization rates have been documented to occur immediately after the 2-day interdialytic interval. ${ }^{163,164}$ A contributing factor may be larger fluid accumulation followed by excessive ultrafiltration and abrupt fluctuations in serum potassium concentrations (Supplementary material online, Figure S1). ${ }^{165}$ In contrast, hypokalaemia is more common in patients on peritoneal dialysis, and hypokalaemia has been associated with increased risk of all-cause, cardiovascular, and infectious mortality in this subgroup of patients. ${ }^{166}$

\section{Treatment options for improving potassium homeostasis}

Treatments for hyperkalaemia include dietary restriction, correction of acidosis, increasing distal sodium load, and loop diuretics, and in the case of hypokalaemia, potassium-sparing diuretics and potassium supplements could be used. ${ }^{167}$ It may be possible to reduce the dose or stop drugs that interfere with potassium homeostasis, such as nonsteroidal anti-inflammatory drugs, sulfamethoxazole-trimethoprim, calcineurin inhibitors, and non-selective beta blockers. Pharmacologic treatments for managing hyperkalaemia include the cation-exchange resin kayaexalate, ${ }^{168}$ calcium-resin resonium, ${ }^{169}$ the potassium-binding polymer patiromer, ${ }^{170}$ and the potassium trap ZS-9. ${ }^{167}$ Beyond the treatment of hyperkalaemia, these agents might also enable more patients with concomitant CKD to be started on or maintained on guideline-recommended renin-angiotensin-aldosterone system (RAAS) inhibitors, and this possibility is currently being investigated. ${ }^{167}$ In addition to reducing serum potassium, patiromer has been shown to reduce serum aldosterone levels in patients with CKD and hyperkalaemia taking RAAS inhibitors. ${ }^{171}$ Other important questions regarding potassium binders relate to their safety and efficacy in postkidney transplant patients, patients with Type IV renal tubular acidosis, or patients taking calcineurin inhibitors.

Data from three clinical trials have indicated that dual RAAS blockade therapy increases the risk of hyperkalaemia in patients with CKD. ${ }^{172-174}$ Meta-analysis data have indicated that mineralocorticoids can mediate hyperkalaemia in patients undergoing dialysis, but large trials are needed to better evaluate this process and its clinical significance. $^{175}$ In patients with Type 2 diabetes, a sodium-glucose cotransporter 2 (SGLT2) inhibitor has been associated with small mean changes in serum electrolytes and less hyperkalaemia compared to placebo, especially in patients taking anti-hypertensives that interfere with potassium excretion. ${ }^{176}$

\section{Dialysate and dialysis parameters}

For patients undergoing haemodialysis, both the potassium concentration in the dialysate and the schedule of haemodialysis treatments affect the risk of sudden death (Figure 6). Potential confounding factors, such as nutrition, treatment compliance, and comorbidities, have not been thoroughly evaluated. It is also not clear whether or how much central venous pressure, hypervolemia, and pulmonary hypertension predispose patients to arrhythmic events. Three studies have indicated that a low potassium dialysate concentration $(<2 \mathrm{mEq} / \mathrm{L})$ is associated 


\section{Table 6 Arrhythmias and chronic kidney disease: current knowledge gaps and future research recommendations}

- Should AF be a required secondary endpoint in future cardiovascular clinical trials among CKD patients? This will enable future studies to examine the contribution of AF to various outcomes (e.g. cognitive impairment).

- Can we improve upon risk assessment in patients with CKD/CKD G5D by examining unique risk factors for stroke (e.g. proteinuria) and bleeding (e.g. proteinuria, platelet dysfunction, vascular access, dialysis anticoagulation)?

- Based on a review of large observational studies, can we ascertain the combinations of risk factors that predict competing SCD vs. non-SCD and cardiac vs. non-cardiac death endpoints in patients with CKD/CKD G5D?

- Are there modifiable risk factors (e.g. long chain omega-3 fatty acids) or pharmacological therapies for SCD worth investigating?

- What is the incidence and prognostic significance of syncope in dialysis patients (on conventional or novel modalities) and transient hypotension, hypovolemia, and bradycardia during and outside dialysis sessions?

- Is there a role for biomarkers (e.g. troponins, BNP) and markers of autonomic dysregulation and sympathetic overactivity in predicting cardiac death and SCD? Is there prognostic significance in incidentally detected arrhythmias?

- Among patients on dialysis, can we use modern imaging techniques (e.g. cardiac magnetic resonance imaging with T1 mapping and speckle tracking imaging echocardiography both during haemodialysis and on a non-dialysis day), long-term ECG monitoring, and emerging biomarkers to ascertain predisposing factors to SCD?

- Since patients with CKD G5D have consistently lower time in TTR values (despite comparable intensity of monitoring) that may contribute to higher risk of bleeding, what is the evidence regarding the role of TTR in decision-making and transitioning to DOAC therapy with suboptimal TTR?

- Estimates of kidney function using eGFR and eCrCl are not equivalent and can lead to important dose discrepancies with DOACs. Both the conference participants and ESC advocate the use of eGFR (over eCrCl) in future trials because of established superiority in estimating kidney function and to reconcile the measure used in pragmatic clinical practice. For adoption of this measure in future trials however, we recognize that there would be need for upfront endorsement of eGFR as the preferred measure for estimating kidney function by regulatory agencies.

- Should serial measurements of kidney function be considered to determine if anticoagulation (e.g. DOACs) is associated with changes in kidney function?

- Does heparin use during haemodialysis alter the risk-benefit ratio when used with concomitant oral anticoagulation? Are there clinical efficacy or safety data evaluating whether the use of erythropoietin therapy influences stroke reduction with anticoagulant therapy?

- Is there utility in employing left atrial appendage occluder devices in patients with CKD G5D who are already at high risk of bleeding and endovascular infections?

- What is the role of DOACs among kidney transplant patients? Do specific drug-drug interactions favour certain agents over others?

- Is ICD therapy efficacious in the primary and secondary prevention of SCD in ESKD? If so, what are the risk-benefit ratios? Utility of leadless pacemakers? Additional studies examining transvenous, subcutaneous, and wearable defibrillators are needed in CKD patients with EF $>35 \%$ since they account for $90 \%$ of ESKD patients.

- What are the long-term outcomes of rate vs. rhythm control in CKD or dialysis patients? What should guide the selection of rate vs. rhythm control in this patient population? For the former, what is the optimal rate control and what are the preferred rate-controlling agents? Utility of transvenous vs. leadless permanent pacemaker following AV node ablation? For rhythm control, what is benefit-risk ratio for ablation vs. antiarrhythmic drugs?

- What is the ideal ablation approach? For antiarrhythmic drugs, are there comparative trials to provide information on safety, pharmacokinetics and efficacy on various agents (especially amiodarone)? Is there a long-term need for oral anticoagulation in patients with successful rhythm control?

- Does personalizing dialysis prescription (e.g. electrolyte dialysate, close monitoring of potassium levels or volume management) reduce the risk for $\mathrm{SCD}$ ? Do changes in other electrolytes associated with arrhythmic predisposition in haemodialysis patients (such as magnesium) affect clinical outcomes?

$\mathrm{AF}$, atrial fibrillation; $\mathrm{AV}$, atrioventricular; $\mathrm{BNP}$, B-type natriuretic peptide; $\mathrm{CKD}$, chronic kidney disease; $\mathrm{DOAC}$, direct oral anticoagulant; $\mathrm{ECG}$, electrocardiogram; eCrCl, estimated creatinine clearance; EF, ejection fraction; eGFR, estimated glomerular filtration rate; ESC, European Society of Cardiology; ESKD, end-stage kidney disease; G5D, CKD stage G5 patients on dialysis therapy; ICD, implantable cardioverter-defibrillator; SCD, sudden cardiac death; TTR, time in therapeutic range.

with a higher incidence of sudden death, especially when pre-dialysis patient serum levels are $<5 \mathrm{mEq} / \mathrm{L} .{ }^{147,177,178}$ For patients with a predialysis serum potassium concentration of $>5 \mathrm{mEq} / \mathrm{L}$, the risks associated with low potassium dialysates have not been statistically significant. In Dialysis Outcomes and Practice Patterns Study (DOPPS), mortality rates were similar in patients prescribed 2 and $3 \mathrm{mEq} / \mathrm{L}$ dialysate. ${ }^{179}$ Rapid correction of acidaemia, low serum or dialysate calcium, and high ultrafiltration rates may contribute to the arrhythmogenic potential of low potassium dialysate. ${ }^{147,180}$ In a study of 50 patients undergoing thrice-weekly dialysis, risk of SCD and significant arrhythmias was greater during the 72-h vs. 48-h breaks. There were no analyses specifically related to potassium levels in these studies. ${ }^{146}$ Whether shortening the interval between haemodialysis sessions could result in clinically significant reductions in sudden cardiac arrest and its relationship to potassium levels is not clear and warrants further study. Dialysate concentrations of bicarbonate, calcium, magnesium, and glutamic acid also are likely to be relevant to risk for arrhythmic events. It is possible that personalizing dialysis parameters 
for individual patients could reduce risk of SCD, but this is untested and would be logistically complicated to implement.

\section{Fluid control during dialysis}

Ultrafiltration rates higher than $10 \mathrm{~mL} / \mathrm{h} / \mathrm{kg}$ have been associated with a higher likelihood of intradialytic hypotension and risk of mortality. ${ }^{181}$ Haemodynamic stress during dialysis induces cardiac stunning, which over time may progress to the development of regional fixed systolic dysfunction, consistent with underlying myocardial hibernation and fibrosis. ${ }^{182} \mathrm{~A}$ retrospective analysis has indicated that greater interdialytic weight gain is associated with an increased risk of cardiovascular morbid events ${ }^{183}$; therefore, strategies that mitigate interdialytic weight gain warrant investigation.

\section{Conclusion}

People with CKD have an increased burden from AF relative to those without $C K D$, and an elevated risk of stroke. For preventing stroke in patients with $\mathrm{eCrCl} 30-50 \mathrm{~mL} / \mathrm{min}$, DOACs are non-inferior to warfarin and have a more favourable safety profile. For CKD G5D patients with $A F$, there are insufficient clinical efficacy and safety data to routinely recommend VKA treatment for preventing stroke.

Evidence from older randomized trials indicates that pharmacological rhythm and rate control strategies are equivalent in terms of their efficacy on risks of heart failure, stroke, and survival. However, catheter ablation, which is superior to antiarrhythmic drug therapy for freedom from AF recurrence, has comparable safety in CKD and non-CKD. The role of AF ablation may continue to evolve, particularly among other co-morbid conditions such as heart failure. Regardless of whether a rhythm or rate strategy is pursued, anticoagulation should also be prescribed unless otherwise contraindicated based on stroke risk.

The risk for SCD is increased in patients with CKD, and for those with ESKD on dialysis, several factors that increase risk have been identified. Studies are needed to identify risk factors for SCD in CKD non-dialysis patients. For preventing SCD in ESKD, primary prevention ICD therapy is indicated in patients with $L V E F \leq 35 \%$, although data on its benefits in these patients are not encouraging. Data regarding secondary prevention ICD therapy indicate some benefits, but further studies are needed to assess long-term risk-benefit ratios in these patients. Available data seem to suggest that the benefit of ICDs decreases with declining GFR.

For patients undergoing haemodialysis, both the potassium concentration in the dialysate and the schedule of haemodialysis treatments affect the risk of sudden death. Whether shortening the interval between haemodialysis sessions could result in clinically significant reductions in sudden cardiac arrest is not yet clear and warrants further study. It is possible that personalizing dialysis parameters for individual patients could reduce risk of SCD, but this is untested and would be logistically complicated to implement.

Recent guidelines include considerable practical and scientific detail on management of these arrhythmias in CKD. ${ }^{3-7,85,184}$ However, there remain substantial evidence gaps, which will require clinical trials, and when not possible, robust observational data. We have outlined research recommendations in the hopes that future investigations can better advance the evidence base in this area (Table 6). A multidisciplinary approach is vital for understanding the mechanisms of arrhythmias in CKD as well as for evaluating therapies and improving clinical care. Nephrologists and cardiologists should initiate and continue partnerships in designing and conducting clinical trials as well as treating individual patients with CKD and AF.

\section{Supplementary material}

Supplementary material is available at European Heart Journal online.

\section{Acknowledgements}

We thank Jennifer King, $\mathrm{PhD}$, for assistance with the manuscript preparation.

\section{Funding}

The conference was sponsored by KDIGO (Kidney Disease: Improving Global Outcomes) and supported in part by unrestricted educational grants from AstraZeneca, Bayer HealthCare, Boston Scientific, DaiichiSankyo, Fresenius Medical Care, Sanofi-Genzyme, Medtronic, Relypsa, and Vifor Fresenius Medical Care Renal Pharma. All conference attendees received travel support for meeting participation.

Conflict of interest: M.P.T. has received research support from AstraZeneca, Boehringer Ingelheim, Cardiva Medical, Janssen, Medtronic, and Veterans Health Administration; has served as a consultant to Akebia, AliveCor, Boehringer Ingelheim, Cardiva Medical, iBeat, iRhythm, Medtronic, Precision Health Economics, and St Jude Medical; has received speaker honoraria from Medscape/theheart.org; has reported equity in AliveCor, iBeat, Zipline Medical; and is an editor for JAMA Cardiology. P.J.B. has received research support from the Dutch Kidney Foundation, the European Commission, Medtronic, The Netherlands Organisation for Health Research and Development, and St. Jude Medical. All monies were paid to institution. J.J.C. has received institutional research grants from AstraZeneca, Vifor Fresenius Medical Care Renal Pharma and Swedish Heart and Lung Foundation and speaker honorarium from Vifor Fresenius Medical Care Renal Pharma. C.A.H. has served as a consultant to Abbvie, Bristol-Myers Squibb, Fibrogen, Relypsa, Sanifit, ZS Pharma; received research support from Amgen and Zoll; owns stock in Boston Scientific, GE, Johnson \& Johnson and Merck. S.E.K. has received research support from WL Gore and Associates, Bayer and Bristol-Myers Squibb; and has served as a consultant to Abbvie, Boehringer Ingelheim and Johnson \& Johnson. R.S.P. has received personal fees from Biotronic and Medtronic; non-financial support from Kardic; and research support from Pfizer. R.P.-F. has served on advisory boards and/or received speaker honoraria from Akebia, AstraZeneca, Baxter, Fresenius Medical Care, Janssen, and Novartis. He has also received research support from Baxter and Fresenius Medical Care. H.R. has received personal fees and non-financial support from Bristol-Myers Squibb and Pfizer. W.Z. has received research support from Boston Scientific and Zoll. D.C.W. has served as a consultant to Amgen, AstraZeneca, Boehringer Ingelheim, GSK, Janssen, and Vifor Fresenius Medical Care Renal Pharma; and has received speaker honoraria from Amgen and Kyowa Kirin. W.C.W. has served as a scientific advisor to AMAG, Amgen, AstraZeneca, Bayer, Daiichi Sankyo, Vifor Fresenius Medical Care Renal Pharma, and ZS Pharma; has served on clinical trial executive committee for Akebia and endpoint adjudication committee for Medtronic; he has also served as a consultant to Relypsa and received speaker honorarium from Fibrogen. C.W. has served as a consultant to BoehringerIngelheim and Sanofi Genzyme. All other authors have nothing to disclose. 


\section{References}

1. Charytan D, Kuntz RE. The exclusion of patients with chronic kidney disease from clinical trials in coronary artery disease. Kidney Int 2006;70:2021-2030.

2. Konstantinidis I, Nadkarni GN, Yacoub R, Saha A, Simoes P, Parikh CR, Coca SG. Representation of patients with kidney disease in trials of cardiovascular interventions: an updated systematic review. JAMA Intern Med 2016;176: 121-124.

3. Boriani G, Savelieva I, Dan GA, Deharo JC, Ferro C, Israel CW, Lane DA, La Manna G, Morton J, Mitjans AM, Vos MA, Turakhia MP, Lip GY. Chronic kidney disease in patients with cardiac rhythm disturbances or implantable electrical devices: clinical significance and implications for decision making-a position paper of the European Heart Rhythm Association endorsed by the Heart Rhythm Society and the Asia Pacific Heart Rhythm Society. Europace 2015;17: 1169-1196.

4. Heidbuchel H, Verhamme P, Alings M, Antz M, Diener HC, Hacke W, Oldgren J, Sinnaeve P, Camm AJ, Kirchhof P. Updated European Heart Rhythm Association Practical Guide on the use of non-vitamin K antagonist anticoagulants in patients with non-valvular atrial fibrillation. Europace 2015;17: 1467-1507.

5. Kirchhof P, Benussi S, Kotecha D, Ahlsson A, Atar D, Casadei B, Castella M, Diener HC, Heidbuchel H, Hendriks J, Hindricks G, Manolis AS, Oldgren J, Popescu BA, Schotten U, Van Putte B, Vardas P, Agewall S, Camm J, Baron Esquivias G, Budts W, Carerj S, Casselman F, Coca A, De Caterina R, Deftereos S, Dobrev D, Ferro JM, Filippatos G, Fitzsimons D, Gorenek B, Guenoun M, Hohnloser SH, Kolh P, Lip GY, Manolis A, McMurray J, Ponikowski P, Rosenhek R, Ruschitzka F, Savelieva I, Sharma S, Suwalski P, Tamargo JL, Taylor C), Van Gelder IC, Voors AA, Windecker S, Zamorano JL, Zeppenfeld K. 2016 ESC Guidelines for the management of atrial fibrillation developed in collaboration with EACTS. Eur Heart J 2016;37:2893-2962.

6. Piepoli MF, Hoes AW, Agewall S, Albus C, Brotons C, Catapano AL, Cooney MT, Corra U, Cosyns B, Deaton C, Graham I, Hall MS, Hobbs FD, Lochen ML, Lollgen H, Marques-Vidal P, Perk J, Prescott E, Redon J, Richter DJ, Sattar N, Smulders Y, Tiberi M, van der Worp HB, van Dis I, Verschuren WM. 2016 European Guidelines on cardiovascular disease prevention in clinical practice: the Sixth Joint Task Force of the European Society of Cardiology and Other Societies on Cardiovascular Disease Prevention in Clinical Practice (constituted by representatives of 10 societies and by invited experts)Developed with the special contribution of the European Association for Cardiovascular Prevention \& Rehabilitation (EACPR). Eur Heart J 2016;37:2315-2381.

7. Priori SG, Blomström-Lundqvist C, Mazzanti A, Blom N, Borggrefe M, Camm J, Elliott PM, Fitzsimons D, Hatala R, Hindricks G, Kirchhof P, Kjeldsen K, Kuck KH, Hernandez-Madrid A, Nikolaou N, Norekvål TM, Spaulding C, Van Veldhuisen DJ. 2015 ESC Guidelines for the management of patients with ventricular arrhythmias and the prevention of sudden cardiac death: the Task Force for the Management of Patients with Ventricular Arrhythmias and the Prevention of Sudden Cardiac Death of the. European Society of Cardiology (ESC). Endorsed by: Association for European Paediatric and Congenital Cardiology (AEPC). Eur Heart J 2015;36:2793-2867.

8. Chugh SS, Havmoeller R, Narayanan K, Singh D, Rienstra M, Benjamin EJ, Gillum RF, Kim YH, McAnulty JH, Jr., Zheng ZJ, Forouzanfar MH, Naghavi M, Mensah GA, Ezzati M, Murray CJ. Worldwide epidemiology of atrial fibrillation: a Global Burden of Disease 2010 Study. Circulation 2014;129: 837-847.

9. Eckardt KU, Coresh J, Devuyst O, Johnson RJ, Kottgen A, Levey AS, Levin A. Evolving importance of kidney disease: from subspecialty to global health burden. Lancet 2013;382:158-169.

10. Soliman EZ, Prineas RJ, Go AS, Xie D, Lash JP, Rahman M, Ojo A, Teal VL, Jensvold NG, Robinson NL, Dries DL, Bazzano L, Mohler ER, Wright JT, Feldman HI, Chronic Renal Insufficiency Cohort SG. Chronic kidney disease and prevalent atrial fibrillation: the Chronic Renal Insufficiency Cohort (CRIC). Am Heart J 2010;159:1102-1107.

11. Ananthapanyasut W, Napan S, Rudolph EH, Harindhanavudhi T, Ayash H, Guglielmi KE, Lerma EV. Prevalence of atrial fibrillation and its predictors in nondialysis patients with chronic kidney disease. Clin J Am Soc Nephrol 2010;5: 173-181.

12. McManus DD, Corteville DC, Shlipak MG, Whooley MA, Ix JH. Relation of kidney function and albuminuria with atrial fibrillation (from the Heart and Soul Study). Am J Cardiol 2009;104:1551-1555.

13. Zimmerman D, Sood MM, Rigatto C, Holden RM, Hiremath S, Clase CM. Systematic review and meta-analysis of incidence, prevalence and outcomes of atrial fibrillation in patients on dialysis. Nephrol Dial Transplant 2012;27: 3816-3822.

14. Wetmore JB, Mahnken JD, Rigler SK, Ellerbeck EF, Mukhopadhyay P, Spertus JA, Hou Q, Shireman TI. The prevalence of and factors associated with chronic atrial fibrillation in Medicare/Medicaid-eligible dialysis patients. Kidney Int 2012; 81:469-476.
15. Genovesi S, Pogliani D, Faini A, Valsecchi MG, Riva A, Stefani F, Acquistapace I, Stella A, Bonforte G, DeVecchi A, DeCristofaro V, Buccianti G, Vincenti A. Prevalence of atrial fibrillation and associated factors in a population of longterm hemodialysis patients. Am J Kidney Dis 2005;46:897-902.

16. Wizemann V, Tong L, Satayathum S, Disney A, Akiba T, Fissell RB, Kerr PG, Young EW, Robinson BM. Atrial fibrillation in hemodialysis patients: clinical features and associations with anticoagulant therapy. Kidney Int 2010;77: 1098-1106.

17. Roy-Chaudhury P, Williamson DE, Tumlin JA, Charytan DM, Prakash K, Kher VK. Arrhythmic risk in patients with type II diabetes on hemodialysis: preliminary results from the Monitoring in Dialysis (MiD) Clinical Study. Abstract THPO805. J Am Soc Nephrol 2015;26:275A.

18. Konigsbrugge O, Posch F, Antlanger M, Kovarik J, Klauser-Braun R, Kletzmayr J, Schmaldienst S, Auinger M, Zuntner G, Lorenz M, Grilz E, Stampfel G, Steiner S, Pabinger I, Saemann M, Ay C. Prevalence of atrial fibrillation and antithrombotic therapy in hemodialysis patients: cross-sectional results of the Vienna InVestigation of AtriaL Fibrillation and Thromboembolism in Patients on HemoDlalysis (VIVALDI). PLoS One 2017;12:e0169400.

19. Alonso A, Lopez FL, Matsushita K, Loehr LR, Agarwal SK, Chen LY, Soliman EZ, Astor BC, Coresh J. Chronic kidney disease is associated with the incidence of atrial fibrillation: the Atherosclerosis Risk in Communities (ARIC) study. Circulation 2011;123:2946-2953.

20. Sandhu RK, Kurth T, Conen D, Cook NR, Ridker PM, Albert CM. Relation of renal function to risk for incident atrial fibrillation in women. Am J Cardiol 2012; 109:538-542.

21. Watanabe H, Watanabe T, Sasaki S, Nagai K, Roden DM, Aizawa Y. Close bidirectional relationship between chronic kidney disease and atrial fibrillation: the Niigata preventive medicine study. Am Heart J 2009;158:629-636.

22. Horio T, Iwashima Y, Kamide K, Tokudome T, Yoshihara F, Nakamura S, Kawano $Y$. Chronic kidney disease as an independent risk factor for new-onset atrial fibrillation in hypertensive patients. / Hypertens 2010;28:1738-1744.

23. Shang W, Li L, Huang S, Zeng R, Huang L, Ge S, Xu G, Sun J. Chronic kidney disease and the risk of new-onset atrial fibrillation: a meta-analysis of prospective cohort studies. PLoS One 2016;11:e0155581.

24. Alonso A, Krijthe BP, Aspelund T, Stepas KA, Pencina MJ, Moser CB, Sinner MF, Sotoodehnia N, Fontes JD, Janssens AC, Kronmal RA, Magnani JW, Witteman JC, Chamberlain AM, Lubitz SA, Schnabel RB, Agarwal SK, McManus DD, Ellinor PT, Larson MG, Burke GL, Launer LJ, Hofman A, Levy D, Gottdiener JS, Kaab S, Couper D, Harris TB, Soliman EZ, Stricker BH, Gudnason V, Heckbert SR, Benjamin Ej. Simple risk model predicts incidence of atrial fibrillation in a racially and geographically diverse population: the CHARGE-AF consortium. J Am Heart Assoc 2013;2:e000102.

25. Deo R, Katz R, Kestenbaum B, Fried L, Sarnak MJ, Psaty BM, Siscovick DS, Shlipak MG. Impaired kidney function and atrial fibrillation in elderly subjects. J Card Fail 2010;16:55-60.

26. Liao JN, Chao TF, Liu CJ, Wang KL, Chen SJ, Lin YJ, Chang SL, Lo LW, Hu YF, Tuan TC, Chung FP, Chen TJ, Chen SA. Incidence and risk factors for newonset atrial fibrillation among patients with end-stage renal disease undergoing renal replacement therapy. Kidney Int 2015;87:1209-1215.

27. Goldstein BA, Arce CM, Hlatky MA, Turakhia M, Setoguchi S, Winkelmayer WC. Trends in the incidence of atrial fibrillation in older patients initiating dialysis in the United States. Circulation 2012;126:2293-2301.

28. Winkelmayer WC, Patrick AR, Liu J, Brookhart MA, Setoguchi S. The increasing prevalence of atrial fibrillation among hemodialysis patients. J Am Soc Nephrol 2011;22:349-357.

29. Providência R, Marijon E, Boveda S, Barra S, Narayanan K, Le Heuzey J-Y, Gersh BJ, Gonçalves L. Meta-analysis of the influence of chronic kidney disease on the risk of thromboembolism among patients with nonvalvular atrial fibrillation. Am J Cardiol 2014;114:646-653.

30. Piccini JP, Stevens SR, Chang Y, Singer DE, Lokhnygina $Y$, Go AS, Patel MR, Mahaffey KW, Halperin JL, Breithardt G, Hankey G], Hacke W, Becker RC, Nessel CC, Fox KA, Califf RM. ROCKET AF Steering Committee and Investigators. Renal dysfunction as a predictor of stroke and systemic embolism in patients with nonvalvular atrial fibrillation: validation of the $\mathrm{R}(2) \mathrm{CHADS}(2)$ index in the ROCKET AF (Rivaroxaban Once-daily, oral, direct factor $\mathrm{Xa}$ inhibition Compared with vitamin $\mathrm{K}$ antagonism for prevention of stroke and Embolism Trial in Atrial Fibrillation) and ATRIA (AnTicoagulation and Risk factors In Atrial fibrillation) study cohorts. Circulation 2013;127:224-232.

31. Olesen JB, Lip GY, Kamper AL, Hommel K, Kober L, Lane DA, Lindhardsen J, Gislason GH, Torp-Pedersen C. Stroke and bleeding in atrial fibrillation with chronic kidney disease. N Engl J Med 2012;367:625-635.

32. Go AS, Fang MC, Udaltsova N, Chang Y, Pomernacki NK, Borowsky L, Singer $\mathrm{DE}$, Investigators AS. Impact of proteinuria and glomerular filtration rate on risk of thromboembolism in atrial fibrillation: the anticoagulation and risk factors in atrial fibrillation (ATRIA) study. Circulation 2009;119:1363-1369. 
33. Wetmore JB, Ellerbeck EF, Mahnken JD, Phadnis M, Rigler SK, Mukhopadhyay P, Spertus JA, Zhou X, Hou Q, Shireman TI. Atrial fibrillation and risk of stroke in dialysis patients. Ann Epidemiol 2013;23:112-118.

34. Conen D, Chae CU, Glynn RJ, Tedrow UB, Everett BM, Buring JE, Albert CM. Risk of death and cardiovascular events in initially healthy women with newonset atrial fibrillation. JAMA 2011;305:2080-2087.

35. Shih CJ, Ou SM, Chao PW, Kuo SC, Lee YJ, Yang CY, Tarng DC, Lin CC, Huang PH, Li SY, Chen YT. Risks of death and stroke in patients undergoing hemodialysis with new-onset atrial fibrillation: a competing-risk analysis of a nationwide cohort. Circulation 2016;133:265-272.

36. Lenihan CR, Montez-Rath ME, Scandling JD, Turakhia MP, Winkelmayer WC. Outcomes after kidney transplantation of patients previously diagnosed with atrial fibrillation. Am J Transplant 2013;13:1566-1575.

37. Findlay MD, Thomson PC, Maclsaac R, Jardine AG, Patel RK, Stevens KK, Rutherford E, Clancy M, Geddes CC, Dawson J, Mark PB. Risk factors and outcome of stroke in renal transplant recipients. Clin Transplant 2016;30: 918-924.

38. Bansal N, Xie D, Tao K, Chen J, Deo R, Horwitz E, Hsu CY, Kallem RK, Keane MG, Lora CM, Raj D, Soliman EZ, Strauss L, Wolf M, Go AS; Study CRIC. Atrial fibrillation and risk of ESRD in adults with CKD. Clin J Am Soc Nephrol 2016;11:1189-1196.

39. Bansal N, Fan D, Hsu CY, Ordonez JD, Marcus GM, Go AS. Incident atrial fibrillation and risk of end-stage renal disease in adults with chronic kidney disease. Circulation 2013;127:569-574.

40. O'Neal WT, Tanner RM, Efird JT, Baber U, Alonso A, Howard VJ, Howard G, Muntner P, Soliman EZ. Atrial fibrillation and incident end-stage renal disease: the REasons for Geographic And Racial Differences in Stroke (REGARDS) study. Int J Cardiol 2015;185:219-223.

41. Bansal N, Fan D, Hsu CY, Ordonez JD, Go AS. Incident atrial fibrillation and risk of death in adults with chronic kidney disease. J Am Heart Assoc 2014;3: e001303.

42. Nelson SE, Shroff GR, Li S, Herzog CA. Impact of chronic kidney disease on risk of incident atrial fibrillation and subsequent survival in medicare patients. J Am Heart Assoc 2012;1:e002097.

43. Chan PH, Huang D, Yip PS, Hai J, Tse HF, Chan TM, Lip GY, Lo WK, Siu CW. Ischaemic stroke in patients with atrial fibrillation with chronic kidney disease undergoing peritoneal dialysis. Europace 2016;18:665-671.

44. Chao TF, Liu CJ, Wang KL, Lin YJ, Chang SL, Lo LW, Hu YF, Tuan TC, Chung FP, Liao JN, Chen TJ, Lip GY, Chen SA. Incidence and prediction of ischemic stroke among atrial fibrillation patients with end-stage renal disease requiring dialysis. Heart Rhythm 2014;11:1752-1759.

45. Friberg L, Benson L, Lip GY. Balancing stroke and bleeding risks in patients with atrial fibrillation and renal failure: the Swedish Atrial Fibrillation Cohort study. Eur Heart J 2015;36:297-306.

46. Roldan V, Marin F, Manzano-Fernandez S, Fernandez H, Gallego P, Valdes M, Vicente $V$, Lip GY. Does chronic kidney disease improve the predictive value of the CHADS2 and CHA2DS2-VASc stroke stratification risk scores for atrial fibrillation? Thromb Haemost 2013;109:956-960.

47. Singer DE, Chang Y, Borowsky LH, Fang MC, Pomernacki NK, Udaltsova N, Reynolds K, Go AS. A new risk scheme to predict ischemic stroke and other thromboembolism in atrial fibrillation: the ATRIA study stroke risk score. / Am Heart Assoc 2013;2:e000250.

48. Kerr KF, Wang Z, Janes H, McClelland RL, Psaty BM, Pepe MS. Net reclassification indices for evaluating risk prediction instruments: a critical review. Epidemiology 2014;25:114-121.

49. January CT, Wann LS, Alpert JS, Calkins H, Cigarroa JE, Cleveland JC, Jr., Conti JB, Ellinor PT, Ezekowitz MD, Field ME, Murray KT, Sacco RL, Stevenson WG, Tchou PJ, Tracy CM, Yancy CW. American College of Cardiology/American Heart Association Task Force on Practice Guidelines. 2014 AHA/ACC/HRS guideline for the management of patients with atrial fibrillation: a report of the American College of Cardiology/American Heart Association Task Force on Practice Guidelines and the Heart Rhythm Society. J Am Coll Cardiol 2014;64: 2246-2276.

50. Bonde AN, Lip GY, Kamper AL, Hansen PR, Lamberts M, Hommel K, Hansen ML, Gislason GH, Torp-Pedersen C, Olesen JB. Net clinical benefit of antithrombotic therapy in patients with atrial fibrillation and chronic kidney disease: a nationwide observational cohort study. J Am Coll Cardiol 2014;64:2471-2482.

51. American College of Chest Physicians Antithrombotic Therapy and Prevention of Thrombosis Panel. Antithrombotic therapy and prevention of thrombosis, 9th Ed: American College of Chest Physicians Evidence-Based Clinical Practice Guidelines. Chest 2012;141(2 Suppl): 1S-70S, e1S-e801S.

52. Kamel H, Okin PM, Elkind MS, ladecola C. Atrial fibrillation and mechanisms of stroke: time for a new model. Stroke 2016;47:895-900.

53. Connolly SJ, Ezekowitz MD, Yusuf S, Eikelboom J, Oldgren J, Parekh A, Pogue J, Reilly PA, Themeles E, Varrone J, Wang S, Alings M, Xavier D, Zhu J, Diaz R, Lewis BS, Darius H, Diener HC, Joyner CD, Wallentin L; RE-LY Steering
Committee and Investigators. Dabigatran versus warfarin in patients with atrial fibrillation. N Engl J Med 2009;361:1139-1151.

54. Patel MR, Mahaffey KW, Garg J, Pan G, Singer DE, Hacke W, Breithardt G, Halperin JL, Hankey GJ, Piccini JP, Becker RC, Nessel CC, Paolini JF, Berkowitz SD, Fox KA, Califf RM; ROCKET AF Investigators. Rivaroxaban versus warfarin in nonvalvular atrial fibrillation. N Engl J Med 2011;365:883-891.

55. Granger CB, Alexander JH, McMurray JJ, Lopes RD, Hylek EM, Hanna M, AlKhalidi HR, Ansell J, Atar D, Avezum A, Bahit MC, Diaz R, Easton JD, Ezekowitz JA, Flaker G, Garcia D, Geraldes M, Gersh B], Golitsyn S, Goto S, Hermosillo AG, Hohnloser SH, Horowitz J, Mohan P, Jansky P, Lewis BS, Lopez-Sendon JL, Pais P, Parkhomenko A, Verheugt FW, Zhu J, Wallentin L; ARISTOTLE Committees and Investigators. Apixaban versus warfarin in patients with atrial fibrillation. N Engl J Med 2011;365:981-992.

56. Giugliano RP, Ruff CT, Braunwald E, Murphy SA, Wiviott SD, Halperin JL, Waldo AL, Ezekowitz MD, Weitz Jl, Spinar J, Ruzyllo W, Ruda M, Koretsune Y, Betcher J, Shi M, Grip LT, Patel SP, Patel I, Hanyok JJ, Mercuri M, Antman EM; ENGAGE AF-TIMI 48 Investigators. Edoxaban versus warfarin in patients with atrial fibrillation. N Engl J Med 2013;369:2093-2104.

57. Hart RG, Pearce LA, Asinger RW, Herzog CA. Warfarin in atrial fibrillation patients with moderate chronic kidney disease. Clin J Am Soc Nephrol 2011;6: 2599-2604.

58. Hijazi Z, Hohnloser SH, Oldgren J, Andersson U, Connolly SJ, Eikelboom JW, Ezekowitz MD, Reilly PA, Siegbahn A, Yusuf S, Wallentin L. Efficacy and safety of dabigatran compared with warfarin in relation to baseline renal function in patients with atrial fibrillation: a RE-LY (Randomized Evaluation of Long-term Anticoagulation Therapy) trial analysis. Circulation 2014;129:961-970.

59. Fox KA, Piccini JP, Wojdyla D, Becker RC, Halperin JL, Nessel CC, Paolini JF, Hankey GJ, Mahaffey KW, Patel MR, Singer DE, Califf RM. Prevention of stroke and systemic embolism with rivaroxaban compared with warfarin in patients with non-valvular atrial fibrillation and moderate renal impairment. Eur Heart J 2011;32:2387-2394.

60. Hohnloser SH, Hijazi Z, Thomas L, Alexander JH, Amerena J, Hanna M, Keltai M, Lanas F, Lopes RD, Lopez-Sendon J, Granger CB, Wallentin L. Efficacy of apixaban when compared with warfarin in relation to renal function in patients with atrial fibrillation: insights from the ARISTOTLE trial. Eur Heart J 2012;33 2821-2830.

61. Eikelboom JW, Connolly SJ, Gao P, Paolasso E, De Caterina R, Husted S, O'donnell M, Yusuf S, Hart RG. Stroke risk and efficacy of apixaban in atrial fibrillation patients with moderate chronic kidney disease. J Stroke Cerebrovasc Dis 2012;21:429-435.

62. Bohula EA, Giugliano RP, Ruff CT, Kuder JF, Murphy SA, Antman EM, Braunwald $E$. Impact of renal function on outcomes with edoxaban in the ENGAGE AF-TIMI 48 trial. Circulation 2016;134:24-36.

63. Qamar A, Bhatt DL. Anticoagulation therapy: balancing the risks of stroke and bleeding in CKD. Nat Rev Nephrol 2015;11:200-202.

64. Lau YC, Proietti M, Guiducci E, Blann AD, Lip GY. Atrial fibrillation and thromboembolism in patients with chronic kidney disease. J Am Coll Cardiol 2016;68:1452-1464.

65. Tan J, Liu S, Segal JB, Alexander GC, McAdams-DeMarco M. Warfarin use and stroke, bleeding and mortality risk in patients with end stage renal disease and atrial fibrillation: a systematic review and meta-analysis. BMC Nephrol 2016; 17:157.

66. Hayashi M, Takamatsu I, Kanno Y, Yoshida T, Abe T, Sato Y, Japanese Calciphylaxis Study G. A case-control study of calciphylaxis in Japanese endstage renal disease patients. Nephrol Dial Transplant 2012;27:1580-1584.

67. Carrero JJ, Evans M, Szummer K, Spaak J, Lindhagen L, Edfors R, Stenvinkel P, Jacobson SH, Jernberg T. Warfarin, kidney dysfunction, and outcomes following acute myocardial infarction in patients with atrial fibrillation. JAMA 2014;311: 919-928.

68. Szummer K, Gasparini A, Eliasson S, Arnlov J, Qureshi AR, Barany P, Evans M, Friberg L, Carrero JJ. Time in therapeutic range and outcomes after warfarin initiation in newly diagnosed atrial fibrillation patients with renal dysfunction. J Am Heart Assoc 2017;6:e004925.

69. Yang F, Hellyer JA, Than C, Ullal AJ, Kaiser DW, Heidenreich PA, Hoang DD, Winkelmayer WC, Schmitt S, Frayne SM, Phibbs CS, Turakhia MP. Warfarin utilisation and anticoagulation control in patients with atrial fibrillation and chronic kidney disease. Heart 2017;103:818-826.

70. Winkelmayer WC, Turakhia MP. Warfarin treatment in patients with atrial fibrillation and advanced chronic kidney disease: sins of omission or commission? Jama 2014;311:913-915.

71. Brodsky SV, Nadasdy T, Rovin BH, Satoskar AA, Nadasdy GM, Wu HM, Bhatt UY, Hebert LA. Warfarin-related nephropathy occurs in patients with and without chronic kidney disease and is associated with an increased mortality rate. Kidney Int 2011;80:181-189.

72. Holden RM, Booth SL. Vascular calcification in chronic kidney disease: the role of vitamin K. Nat Clin Pract Nephrol 2007;3:522-523. 
73. Kooiman J, van der Hulle T, Maas H, Wiebe S, Formella S, Clemens A, van Buren M, Janssen M, Rabelink TJ, Huisman MV. Pharmacokinetics and pharmacodynamics of dabigatran $75 \mathrm{mg}$ b.i.d. in patients with severe chronic kidney disease. J Am Coll Cardiol 2016;67:2442-2444.

74. Dias C, Moore KT, Murphy J, Ariyawansa J, Smith W, Mills RM, Weir MR. Pharmacokinetics, pharmacodynamics, and safety of single-dose rivaroxaban in chronic hemodialysis. Am J Nephrol 2016;43:229-236.

75. De Vriese AS, Caluwe R, Bailleul E, De Bacquer D, Borrey D, Van Vlem B, Vandecasteele SJ, Emmerechts J. Dose-finding study of rivaroxaban in hemodialysis patients. Am J Kidney Dis 2015;66:91-98.

76. Wang X, Tirucherai G, Marbury TC, Wang J, Chang M, Zhang D, Song Y, Pursley J, Boyd RA, Frost C. Pharmacokinetics, pharmacodynamics, and safety of apixaban in subjects with end-stage renal disease on hemodialysis. J Clin Pharmacol 2016;56:628-636.

77. Mavrakanas TA, Samer CF, Nessim SJ, Frisch G, Lipman ML. Apixaban pharmacokinetics at steady state in hemodialysis patients. J Am Soc Nephrol 2017;28: 2241-2248.

78. Matzke GR, Aronoff GR, Atkinson AJ, Jr., Bennett WM, Decker BS, Eckardt KU, Golper T, Grabe DW, Kasiske B, Keller F, Kielstein JT, Mehta R, Mueller BA, Pasko DA, Schaefer F, Sica DA, Inker LA, Umans JG, Murray P. Drug dosing consideration in patients with acute and chronic kidney disease-a clinical update from Kidney Disease: improving Global Outcomes (KDIGO). Kidney. Int 2011; 80:1122-1137

79. Manzano-Fernández S, Andreu-Cayuelas JM, Marín F, Orenes-Piñero E, Gallego P, Valdés M, Vicente V, Lip GYH, Roldán V. Comparison of estimated glomerular filtration rate equations for dosing new oral anticoagulants in patients with atrial fibrillation. Rev Esp Cardiol (Engl Ed) 2015;68:497-504.

80. Kidney Disease: Improving Global Outcomes (KDIGO) CKD Work Group. KDIGO 2012 clinical practice guideline for the evaluation and management of chronic kidney disease. Kidney Int 2013;3 (Suppl): 1-150.

81. Chan KE, Edelman ER, Wenger JB, Thadhani RI, Maddux FW. Dabigatran and rivaroxaban use in atrial fibrillation patients on hemodialysis. Circulation 2015; 131:972-979.

82. Winkelmayer WC, Herzog CA, Montez-Rath ME, Chang TI, Chertow GM. Use of novel oral anticoagulants in patients with end-stage renal disease. Hemodial Int 2015:19:150-153.

83. Shroff GR. Renal function in patients with atrial fibrillation receiving anticoagulants: the canaries in the coal mine. JAMA Cardiol 2016;1:375-376.

84. Yao X, Shah ND, Sangaralingham LR, Gersh BJ, Noseworthy PA. Non-vitamin K antagonist oral anticoagulant dosing in patients with atrial fibrillation and renal dysfunction. J Am Coll Cardiol 2017;69:2779-2790.

85. Kirchhof P, Breithardt G, Bax J, Benninger G, Blomstrom-Lundqvist C, Boriani G, Brandes A, Brown H, Brueckmann M, Calkins H, Calvert M, Christoffels V, Crijns H, Dobrev D, Ellinor P, Fabritz L, Fetsch T, Freedman SB, Gerth A, Goette A, Guasch E, Hack G, Haegeli L, Hatem S, Haeusler KG, Heidbuchel H, Heinrich-Nols J, Hidden-Lucet F, Hindricks G, Juul-Moller S, Kaab S, Kappenberger L, Kespohl S, Kotecha D, Lane DA, Leute A, Lewalter T, Meyer R, Mont L, Munzel F, Nabauer M, Nielsen JC, Oeff M, Oldgren J, Oto A, Piccini JP, Pilmeyer A, Potpara T, Ravens U, Reinecke H, Rostock T, Rustige J, Savelieva I, Schnabel R, Schotten U, Schwichtenberg L, Sinner MF, Steinbeck G, Stoll M, Tavazzi L, Themistoclakis S, Tse HF, Van Gelder IC, Vardas PE, Varpula T, Vincent A, Werring D, Willems S, Ziegler A, Lip GY, Camm AJ. A roadmap to improve the quality of atrial fibrillation management: proceedings from the fifth Atrial Fibrillation Network/European Heart Rhythm Association consensus conference. Europace 2016;18:37-50.

86. Bohm M, Ezekowitz MD, Connolly SJ, Eikelboom JW, Hohnloser SH, Reilly PA, Schumacher H, Brueckmann M, Schirmer SH, Kratz MT, Yusuf S, Diener HC, Hijazi Z, Wallentin L. Changes in renal function in patients with atrial fibrillation: an analysis from the RE-LY trial. J Am Coll Cardiol 2015;65: 2481-2493.

87. Doherty JU, Gluckman TJ, Hucker WJ, Januzzi JL, Jr., Ortel TL, Saxonhouse SJ, Spinler SA. 2017 ACC expert consensus decision pathway for periprocedural management of anticoagulation in patients with nonvalvular atrial fibrillation: a Report of the American College of Cardiology Clinical Expert Consensus Document Task Force. J Am Coll Cardiol 2017;69:871-898.

88. Janssen MJ, Huijgens PC, Bouman AA, Oe PL, Donker AJ, van der Meulen J. Citrate versus heparin anticoagulation in chronic haemodialysis patients. Nephrol Dial Transplant 1993;8:1228-1233.

89. Glund S, Stangier J, van Ryn J, Schmohl M, Moschetti V, Haazen W, De Smet M, Gansser D, Norris S, Lang B, Reilly P, Kreuzer J. Effect of age and renal function on idarucizumab pharmacokinetics and idarucizumab-mediated reversal of dabigatran anticoagulant activity in a randomized, double-blind, crossover phase $\mathrm{lb}$ study. Clin Pharmacokinet 2017;56:41-54.

90. Connolly SJ, Eikelboom J, Joyner C, Diener HC, Hart R, Golitsyn S, Flaker G, Avezum A, Hohnloser SH, Diaz R, Talajic M, Zhu J, Pais P, Budaj A, Parkhomenko A, Jansky P, Commerford P, Tan RS, Sim KH, Lewis BS, Van
Mieghem W, Lip GY, Kim JH, Lanas-Zanetti F, Gonzalez-Hermosillo A, Dans AL, Munawar M, O’Donnell M, Lawrence J, Lewis G, Afzal R, Yusuf S. Apixaban in patients with atrial fibrillation. N Engl J Med 2011;364:806-817.

91. Gibson CM, Mehran R, Bode C, Halperin J, Verheugt FW, Wildgoose P, Birmingham M, lanus J, Burton P, van Eickels M, Korjian S, Daaboul Y, Lip GY, Cohen M, Husted S, Peterson ED, Fox KA. Prevention of bleeding in patients with atrial fibrillation undergoing PCI. N Engl J Med 2016;375:2423-2434.

92. Reddy VY, Doshi SK, Kar S, Gibson DN, Price MJ, Huber K, Horton RP, Buchbinder M, Neuzil P, Gordon NT, Holmes DR Jr. 5-year outcomes after left atrial appendage closure: from the PREVAIL and PROTECT AF trials. J Am Coll Cardiol 2017;70:2964-2975.

93. Kefer J, Tzikas A, Freixa X, Shakir S, Gafoor S, Nielsen-Kudsk JE, Berti S, Santoro G, Aminian A, Landmesser U, Nietlispach F, Ibrahim R, Danna PL, Benit E, Budts W, Stammen F, De Potter T, Tichelbacker T, Gloekler S, Kanagaratnam P, Costa M, Cruz-Gonzalez I, Sievert H, Schillinger W, Park JW, Meier B, Omran $\mathrm{H}$. Impact of chronic kidney disease on left atrial appendage occlusion for stroke prevention in patients with atrial fibrillation. Int J Cardiol 2016;207:335-340.

94. Wyse DG, Waldo AL, DiMarco JP, Domanski MJ, Rosenberg Y, Schron EB, Kellen JC, Greene HL, Mickel MC, Dalquist JE, Corley SD; Atrial Fibrillation Follow-up Investigation of Rhythm Management Investigators. A comparison of rate control and rhythm control in patients with atrial fibrillation. N Engl ] Med 2002;347:1825-1833.

95. Testa L, Biondi-Zoccai GG, Dello Russo A, Bellocci F, Andreotti F, Crea F. Rate-control vs. rhythm-control in patients with atrial fibrillation: a meta-analysis. Eur Heart J 2005;26:2000-2006.

96. Chatterjee S, Sardar P, Lichstein E, Mukherjee D, Aikat S. Pharmacologic rate versus rhythm-control strategies in atrial fibrillation: an updated comprehensive review and meta-analysis. Pacing Clin Electrophysiol 2013;36:122-133.

97. Wyse DG. Rate control vs rhythm control strategies in atrial fibrillation. Prog Cardiovasc Dis 2005;48:125-138.

98. Verde E, Perez de Prado A, Lopez-Gomez JM, Quiroga B, Goicoechea M, Garcia-Prieto A, Torres E, Reque J, Luno J. Asymptomatic intradialytic supraventricular arrhythmias and adverse outcomes in patients on hemodialysis. Clin J Am Soc Nephrol 2016;11:2210-2217.

99. Van Gelder IC, Groenveld HF, Crijns HJ, Tuininga YS, Tijssen JG, Alings AM, Hillege HL, Bergsma-Kadijk JA, Cornel JH, Kamp O, Tukkie R, Bosker HA, Van Veldhuisen DJ, Van den Berg MP; RACE II Investigators. Lenient versus strict rate control in patients with atrial fibrillation. N Engl J Med 2010;362 1363-1373.

100. Williams ES, Thompson VP, Chiswell KE, Alexander JH, White HD, Ohman EM, Al-Khatib SM. Rate versus rhythm control and outcomes in patients with atrial fibrillation and chronic kidney disease: data from the GUSTO-III Trial. Cardiol J 2013;20:439-446

101. Potpara TS, Jokic V, Dagres N, Marin F, Prostran MS, Blomstrom-Lundqvist C, Lip GY. Cardiac arrhythmias in patients with chronic kidney disease: implications of renal failure for antiarrhythmic drug therapy. Curr Med Chem 2016;23. 2070-2083.

102. Weir MA, Dixon SN, Fleet JL, Roberts MA, Hackam DG, Oliver MJ, Suri RS, Quinn RR, Ozair S, Beyea MM, Kitchlu A, Garg AX. beta-Blocker dialyzability and mortality in older patients receiving hemodialysis. J Am Soc Nephrol 2015 26:987-996.

103. Hoffmann KJ, Regardh CG, Aurell M, Ervik M, Jordo L. The effect of impaired renal function on the plasma concentration and urinary excretion of metoprolol metabolites. Clin Pharmacokinet 1980;5:181-191.

104. https://www.drugbank.ca/drugs/DB00598 (13 February 2018).

105. Daheb K, Lipman ML, Hildgen P, Roy J]. Artificial neural network modeling for drug dialyzability prediction. J Pharm Pharm Sci 2013;16:665-675.

106. Frishman WSD. Cardiovascular Pharmacotherapies. Minneapolis, MN: Cardiotext Publisher; 2011.

107. Dasgupta A, Montalvo J, Medendorp S, Lloyd-Jones DM, Ghossein C, Goldberger J, Passman R. Increased complication rates of cardiac rhythm management devices in ESRD patients. Am J Kidney Dis 2007;49:656-663.

108. Reinecke H, Nabauer M, Gerth A, Limbourg T, Treszl A, Engelbertz C, Eckardt L, Kirchhof P, Wegscheider K, Ravens U, Meinertz T, Steinbeck G, Breithardt G, Afnet SG. Morbidity and treatment in patients with atrial fibrillation and chronic kidney disease. Kidney Int 2015;87:200-209.

109. Schmidt M, Daccarett M, Rittger H, Marschang H, Holzmann S, Jung P, Bojanic $D$, Ketteler M, Brachmann J, Rieber J. Renal dysfunction and atrial fibrillation recurrence following cardioversion. J Cardiovasc Electrophysiol 2011;22:1092-1098. 110. https://www.drugbank.ca/drugs/DB01182 (13 February 2018).

111. Ullal AJ, Than CT, Fan J, Schmitt S, Perino AC, Kaiser DW, Heidenreich PA, Frayne SM, Phibbs CS, Turakhia MP. Amiodarone and risk of death in contemporary patients with atrial fibrillation: findings from the Retrospective Evaluation and Assessment of Therapies in AF study. Am Heart J 2015;170: 1033-1041. 
112. Ullal AJ, Kaiser DW, Fan J, Schmitt S, Than CT, Winkelmayer WC, Heidenreich PA, Piccini JP, Perez MV, Wang PJ, Turakhia MP. Safety and clinical outcomes of catheter ablation of atrial fibrillation in patients with chronic kidney disease. J Cardiovasc Electrophysiol 2017;28:39-48.

113. Li M, Liu T, Luo D, Li G. Systematic review and meta-analysis of chronic kidney disease as predictor of atrial fibrillation recurrence following catheter ablation. Cardiol J 2014;21:89-95.

114. Yanagisawa S, Inden $Y$, Kato H, Fujii A, Mizutani $Y$, Ito T, Kamikubo $Y$, Kanzaki $Y$, Ando M, Hirai M, Shibata R, Murohara T. Impaired renal function is associated with recurrence after cryoballoon catheter ablation for paroxysmal atrial fibrillation: a potential effect of non-pulmonary vein foci. J Cardiol 2017;69:3-10.

115. Takahashi Y, Takahashi A, Kuwahara T, Okubo K, Fujino T, Takagi K, Nakashima E, Kamiishi T, Hikita H, Hirao K, Isobe M. Renal function after catheter ablation of atrial fibrillation. Circulation 2011;124:2380-2387.

116. Marrouche NF, Brachmann J, Andresen D, Siebels J, Boersma L, Jordaens L, Merkely B, Pokushalov E, Sanders P, Proff J, Schunkert H, Christ H, Vogt J, Bänsch D; CASTLE-AF Investigators. Catheter ablation for atrial fibrillation with heart failure. N Engl J Med 2018;378:417-427.

117. Marrouche NF, Brachmann J. Catheter ablation versus standard conventional treatment in patients with left ventricular dysfunction and atrial fibrillation (CASTLE-AF) —study design. Pacing Clin Electrophysiol 2009;32:987-994.

118. Kwon CH, Kim J, Kim MS, Roh JH, Choi JH, Jo U, Lee WS, Kim YR, Nam GB, Choi KJ, Kim YH. Impact of impaired renal function on the incidence of atrial fibrillation following radiofrequency ablation of cavotricuspid isthmusdependent atrial flutter. Korean Circ J 2015;45:473-478.

119. Abed HS, Wittert GA, Leong DP, Shirazi MG, Bahrami B, Middeldorp ME, Lorimer MF, Lau DH, Antic NA, Brooks AG, Abhayaratna WP, Kalman JM, Sanders P. Effect of weight reduction and cardiometabolic risk factor management on symptom burden and severity in patients with atrial fibrillation: a randomized clinical trial. JAMA 2013;310:2050-2060.

120. Lakkireddy D, Atkins D, Pillarisetti J, Ryschon K, Bommana S, Drisko J, Vanga S, Dawn B. Effect of yoga on arrhythmia burden, anxiety, depression, and quality of life in paroxysmal atrial fibrillation: the YOGA My Heart Study. I Am Coll Cardiol 2013;61:1177-1182.

121. Gami AS, Pressman G, Caples SM, Kanagala R, Gard JJ, Davison DE, Malouf JF, Ammash NM, Friedman PA, Somers VK. Association of atrial fibrillation and obstructive sleep apnea. Circulation 2004;110:364-367.

122. Li L, Wang ZW, Li J, Ge X, Guo LZ, Wang Y, Guo WH, jiang CX, Ma CS. Efficacy of catheter ablation of atrial fibrillation in patients with obstructive sleep apnoea with and without continuous positive airway pressure treatment: a meta-analysis of observational studies. Europace 2014;16:1309-1314.

123. Meyring-Wosten A, Zhang $H$, Ye X, Fuertinger DH, Chan L, Kappel F, Artemyev M, Ginsberg N, Wang Y, Thijssen S, Kotanko P. Intradialytic hypoxemia and clinical outcomes in patients on hemodialysis. Clin J Am Soc Nephrol 2016;11:616-625.

124. Unruh ML, Sanders MH, Redline S, Piraino BM, Umans JG, Hammond TC, Sharief I, Punjabi NM, Newman AB. Sleep apnea in patients on conventional thrice-weekly hemodialysis: comparison with matched controls from the Sleep Heart Health Study. J Am Soc Nephrol 2006;17:3503-3509.

125. Tuohy CV, Montez-Rath ME, Turakhia M, Chang TI, Winkelman JW, Winkelmayer WC. Sleep disordered breathing and cardiovascular risk in older patients initiating dialysis in the United States: a retrospective observational study using medicare data. BMC Nephrol 2016;17:16.

126. Charytan DM, Lewis EF, Desai AS, Weinrauch LA, Ivanovich P, Toto RD, Claggett B, Liu J, Hartley LH, Finn P, Singh AK, Levey AS, Pfeffer MA, McMurray Jj, Solomon SD. Cause of death in patients with diabetic CKD enrolled in the Trial to Reduce Cardiovascular Events With Aranesp Therapy (TREAT). Am J Kidney Dis 2015;66:429-440.

127. Deo R, Lin F, Vittinghoff E, Tseng ZH, Hulley SB, Shlipak MG. Kidney dysfunction and sudden cardiac death among women with coronary heart disease. Hypertension 2008;51:1578-1582.

128. Deo R, Sotoodehnia N, Katz R, Sarnak MJ, Fried LF, Chonchol M, Kestenbaum B, Psaty BM, Siscovick DS, Shlipak MG. Cystatin C and sudden cardiac death risk in the elderly. Circ Cardiovasc Qual Outcomes 2010;3:159-164.

129. Goldenberg I, Moss AJ, McNitt S, Zareba W, Andrews ML, Hall WJ, Greenberg $\mathrm{H}$, Case RB, Multicenter Automatic Defibrillator Implantation Trial III. Relations among renal function, risk of sudden cardiac death, and benefit of the implanted cardiac defibrillator in patients with ischemic left ventricular dysfunction. Am J Cardiol 2006;98:485-490.

130. Pun PH, Smarz TR, Honeycutt EF, Shaw LK, Al-Khatib SM, Middleton JP. Chronic kidney disease is associated with increased risk of sudden cardiac death among patients with coronary artery disease. Kidney Int 2009;76:652-658.

131. Saxon LA, Bristow MR, Boehmer J, Krueger S, Kass DA, De Marco T, Carson P, DiCarlo L, Feldman AM, Galle E, Ecklund F. Predictors of sudden cardiac death and appropriate shock in the Comparison of Medical Therapy, Pacing, and Defibrillation in Heart Failure (COMPANION) Trial. Circulation 2006;114:2766-2772
132. Suzuki T, Agarwal SK, Deo R, Sotoodehnia N, Grams ME, Selvin E, Calkins $H$, Rosamond W, Tomaselli G, Coresh J, Matsushita K. Kidney function and sudden cardiac death in the community: the Atherosclerosis Risk in Communities (ARIC) Study. Am Heart / 2016;180:46-53.

133. Bleyer AJ, Hartman J, Brannon PC, Reeves-Daniel A, Satko SG, Russell G. Characteristics of sudden death in hemodialysis patients. Kidney Int 2006;69: 2268-2273.

134. Chan KE, Maddux FW, Tolkoff-Rubin N, Karumanchi SA, Thadhani R, Hakim RM. Early outcomes among those initiating chronic dialysis in the United States. Clin J Am Soc Nephrol 2011;6:2642-2649.

135. Herzog CA, Asinger RW, Berger AK, Charytan DM, Diez J, Hart RG, Eckardt KU, Kasiske BL, McCullough PA, Passman RS, DeLoach SS, Pun PH, Ritz E. Cardiovascular disease in chronic kidney disease. A clinical update from Kidney Disease: improving Global Outcomes (KDIGO). Kidney Int 2011;80 572-586.

136. Herzog CA, Mangrum JM, Passman R. Sudden cardiac death and dialysis patients. Semin Dial 2008;21:300-307.

137. Robinson BM, Zhang J, Morgenstern H, Bradbury BD, Ng LJ, McCullough KP, Gillespie BW, Hakim R, Rayner H, Fort J, Akizawa T, Tentori F, Pisoni RL. Worldwide, mortality risk is high soon after initiation of hemodialysis. Kidney Int 2014;85:158-165.

138. Weinhandl E, Constantini E, Everson S, Gilbertson D, Li S, Solid C, Anger M, Bhat JG, DeOreo P, Krishnan M, Nissenson A, Johnson D, Ikizler TA, Maddux F. Sadler J, Tyshler L, Parker T, 3rd, Schiller B, Smith B, Lindenfeld S, Collins AJ. Peer kidney care initiative 2014 report: dialysis care and outcomes in the United States. Am J Kidney Dis 2015;65:A6.

139. U.S. Renal Data System, 2017 USRDS Annual Data Report: Epidemiology of kidney disease in the United States. Bethesda, MD: National Institutes of Health, National Institute of Diabetes and Digestive and Kidney Diseases, 2017.

140. Wetmore JB, Gilbertson DT, Liu J, Collins AJ. Improving outcomes in patients receiving dialysis: the peer kidney care initiative. Clin J Am Soc Nephrol 2016;11 1297-1304.

141. Chugh SS, Reinier K, Teodorescu C, Evanado A, Kehr E, Al Samara M, Mariani R, Gunson K, Jui J. Epidemiology of sudden cardiac death: clinical and research implications. Prog Cardiovasc Dis 2008;51:213-228.

142. Desai AS, McMurray JJ, Packer M, Swedberg K, Rouleau JL, Chen F, Gong J, Rizkala AR, Brahimi A, Claggett B, Finn PV, Hartley LH, Liu J, Lefkowitz M, Shi $\checkmark$, Zile MR, Solomon SD. Effect of the angiotensin-receptor-neprilysin inhibitor LCZ696 compared with enalapril on mode of death in heart failure patients. Eur Heart J 2015;36:1990-1997.

143. Solomon SD, Zelenkofske S, McMurray JJ, Finn PV, Velazquez E, Ertl G, Harsanyi A, Rouleau JL, Maggioni A, Kober L, White H, Van de Werf F, Pieper K, Califf RM, Pfeffer MA. Sudden death in patients with myocardial infarction and left ventricular dysfunction, heart failure, or both. N Engl J Med 2005;352: 2581-2588.

144. Pun PH, Herzog CA, Middleton JP. Improving ascertainment of sudden cardiac death in patients with end stage renal disease. Clin J Am Soc Nephrol 2012;7: 116-122.

145. Wan C, Herzog CA, Zareba W, Szymkiewicz SJ. Sudden cardiac arrest in hemodialysis patients with wearable cardioverter defibrillator. Ann Noninvasive Electrocardiol 2014;19:247-257.

146. Wong MC, Kalman JM, Pedagogos E, Toussaint N, Vohra JK, Sparks PB, Sanders P, Kistler PM, Halloran K, Lee G, Joseph SA, Morton JB. Temporal distribution of arrhythmic events in chronic kidney disease: highest incidence in the long interdialytic period. Heart Rhythm 2015;12:2047-2055.

147. Pun PH, Lehrich RW, Honeycutt EF, Herzog CA, Middleton JP. Modifiable risk factors associated with sudden cardiac arrest within hemodialysis clinics. Kidney Int 2011;79:218-227.

148. Shastri S, Tangri N, Tighiouart H, Beck GJ, Vlagopoulos P, Ornt D, Eknoyan G, Kusek JW, Herzog C, Cheung AK, Sarnak MJ. Predictors of sudden cardiac death: a competing risk approach in the hemodialysis study. Clin J Am Soc Nephrol 2012; 7:123-130.

149. Friedman AN, Yu Z, Tabbey R, Denski C, Tamez H, Wenger J, Thadhani R, Li Y, Watkins BA. Inverse relationship between long-chain n-3 fatty acids and risk of sudden cardiac death in patients starting hemodialysis. Kidney Int 2013;83:1130-1135.

150. Kruzan RM, Herzog CA, Wu A, Sang Y, Parekh RS, Matsushita K, Hwang S, Cheng A, Coresh J, Powe NR, Shafi T. Association of NTproBNP and cTnl with outpatient sudden cardiac death in hemodialysis patients: the Choices for Healthy Outcomes in Caring for ESRD (CHOICE) study. BMC Nephrol 2016;17:18.

151. Sandoval Y, Herzog CA, Love SA, Cao J, Hu Y, Wu AH, Gilbertson D, Brunelli SM, Young A, Ler R, Apple FS. Prognostic value of serial changes in highsensitivity cardiac troponin I and T over 3 months using reference change values in hemodialysis patients. Clin Chem 2016;62:631-638.

152. Wang AY, Lam CW, Chan IH, Wang M, Lui SF, Sanderson JE. Sudden cardiac death in end-stage renal disease patients: a 5-year prospective analysis. Hypertension 2010;56:210-216. 
153. Winkler K, Wanner C, Drechsler C, Lilienthal J, Marz W, Krane V; German Diabetes and Dialysis Study Investigators. Change in N-terminal-pro-B-typenatriuretic-peptide and the risk of sudden death, stroke, myocardial infarction, and all-cause mortality in diabetic dialysis patients. Eur Heart J 2008;29: 2092-2099.

154. Katritsis DG, Zareba W, Camm AJ. Nonsustained ventricular tachycardia. J Am Coll Cardiol 2012;60:1993-2004.

155. Roberts R, Jeffrey C, Carlisle G, Brierley E. Prospective investigation of the incidence of falls, dizziness and syncope in haemodialysis patients. Int Urol Nephrol 2007;39:275-279.

156. Charytan DM, Patrick AR, Liu J, Setoguchi S, Herzog CA, Brookhart MA, Winkelmayer WC. Trends in the use and outcomes of implantable cardioverter-defibrillators in patients undergoing dialysis in the United States. Am J Kidney Dis 2011;58:409-417.

157. Herzog CA, Li S, Weinhandl ED, Strief JW, Collins AJ, Gilbertson DT. Survival of dialysis patients after cardiac arrest and the impact of implantable cardioverter defibrillators. Kidney Int 2005;68:818-825.

158. Nakhoul GN, Schold JD, Arrigain S, Harb SC, Jolly S, Wilkoff BL, Nally JV, Jr, Navaneethan SD. Implantable cardioverter-defibrillators in patients with CKD: a propensity-matched mortality analysis. Clin J Am Soc Nephrol 2015;10: 1119-1127.

159. Mallamaci F, Zoccali C, Tripepi G, Benedetto FA, Parlongo S, Cataliotti A, Cutrupi S, Giacone G, Bellanuova I, Stancanelli B, Malatino LS. Diagnostic potential of cardiac natriuretic peptides in dialysis patients. Kidney Int 2001;59: 1559-1566.

160. Sood MM, Pauly RP, Rigatto C, Komenda P. Left ventricular dysfunction in the haemodialysis population. NDT Plus 2008;1:199-205.

161. Pun PH, Al-Khatib SM, Han JY, Edwards R, Bardy GH, Bigger JT, Buxton AE, Moss AJ, Lee KL, Steinman R, Dorian P, Hallstrom A, Cappato R, Kadish AH, Kudenchuk PJ, Mark DB, Hess PL, Inoue LY, Sanders GD. Implantable cardioverter-defibrillators for primary prevention of sudden cardiac death in CKD: a meta-analysis of patient-level data from 3 randomized trials. Am J Kidney Dis 2014;64:32-39.

162. El-Chami MF, Levy M, Kelli HM, Casey M, Hoskins MH, Goyal A, Langberg JJ, Patel A, Delurgio D, Lloyd MS, Leon AR, Merchant FM. Outcome of subcutaneous implantable cardioverter defibrillator implantation in patients with end-stage renal disease on dialysis. J Cardiovasc Electrophysiol 2015;26: 900-904.

163. Fotheringham J, Fogarty DG, El Nahas M, Campbell MJ, Farrington K. The mortality and hospitalization rates associated with the long interdialytic gap in thrice-weekly hemodialysis patients. Kidney Int 2015;88:569-575.

164. Brunelli SM, Du Mond C, Oestreicher N, Rakov V, Spiegel DM. Serum potassium and short-term clinical outcomes among hemodialysis patients: impact of the long interdialytic interval. Am J Kidney Dis 2017;70:21-29.

165. Rhee CM, Kalantar-Zadeh K. Implications of the long interdialytic gap: a problem of excess accumulation vs. excess removal? Kidney Int 2015;88:442-444.

166. Ribeiro SC, Figueiredo AE, Barretti P, Pecoits-Filho R, de Moraes TP, Aguilera Al. all centers that contributed to Blls. Low serum potassium levels increase the infectious-caused mortality in peritoneal dialysis patients: a Propensity-Matched Score Study. PLoS One 2015;10:e0127453.

167. Pitt B, Rossignol P. Potassium lowering agents: recommendations for physician and patient education, treatment reappraisal, and serial monitoring of potassium in patients with chronic hyperkalemia. Pharmacol Res 2017;118:2-4.

168. Lepage L, Dufour AC, Doiron J, Handfield K, Desforges K, Bell R, Vallee M, Savoie M, Perreault S, Laurin LP, Pichette V, Lafrance JP. Randomized clinical trial of sodium polystyrene sulfonate for the treatment of mild hyperkalemia in CKD. Clin J Am Soc Nephrol 2015;10:2136-2142.

169. Berlyne GM, Janabi K, Shaw AB, Hocken AG. Treatment of hyperkalemia with a calcium-resin. Lancet 1966;1:169-172.

170. Weir MR, Bakris GL, Bushinsky DA, Mayo MR, Garza D, Stasiv Y, Wittes J, Christ-Schmidt H, Berman L, Pitt B. Patiromer in patients with kidney disease and hyperkalemia receiving RAAS inhibitors. N Engl J Med 2015;372: 211-221.
171. Weir MR, Bakris GL, Gross C, Mayo MR, Garza D, Stasiv Y, Yuan J, Berman L, Williams $\mathrm{GH}$. Treatment with patiromer decreases aldosterone in patients with chronic kidney disease and hyperkalemia on renin-angiotensin system inhibitors. Kidney Int 2016;90:696-704.

172. ONTARGET Investigators, Yusuf S, Teo KK, Pogue J, Dyal L, Copland I, Schumacher H, Dagenais G, Sleight P, Anderson C. Telmisartan, ramipril, or both in patients at high risk for vascular events. N Engl J Med 2008;358: 1547-1559.

173. Parving HH, Brenner BM, McMurray JJ, de Zeeuw D, Haffner SM, Solomon SD, Chaturvedi N, Persson F, Desai AS, Nicolaides M, Richard A, Xiang Z, Brunel P, Pfeffer MA; ALTITUDE Investigators. Cardiorenal end points in a trial of aliskiren for type 2 diabetes. N Engl J Med 2012;367:2204-2213.

174. Fried LF, Emanuele N, Zhang JH, Brophy M, Conner TA, Duckworth W, Leehey DJ, McCullough PA, O'Connor T, Palevsky PM, Reilly RF, Seliger SL, Warren SR, Watnick S, Peduzzi P, Guarino P; VA NEPHRON-D Investigators. Combined angiotensin inhibition for the treatment of diabetic nephropathy. $N$ Engl J Med 2013;369:1892-1903.

175. Quach K, Lvtvyn L, Baigent C, Bueti J, Garg AX, Hawley C, Haynes R, Manns B, Perkovic V, Rabbat CG, Wald R, Walsh M. The safety and efficacy of mineralocorticoid receptor antagonists in patients who require dialysis: a systematic review and meta-analysis. Am J Kidney Dis 2016;68:591-598.

176. Weir MR, Kline I, Xie J, Edwards R, Usiskin K. Effect of canagliflozin on serum electrolytes in patients with type 2 diabetes in relation to estimated glomerular filtration rate (eGFR). Curr Med Res Opin 2014;30:1759-1768.

177. Karnik JA, Young BS, Lew NL, Herget M, Dubinsky C, Lazarus JM, Chertow GM. Cardiac arrest and sudden death in dialysis units. Kidney Int 2001;60: 350-357.

178. Jadoul M, Thumma J, Fuller DS, Tentori F, Li Y, Morgenstern H, Mendelssohn D, Tomo T, Ethier J, Port F, Robinson BM. Modifiable practices associated with sudden death among hemodialysis patients in the Dialysis Outcomes and Practice Patterns Study. Clin J Am Soc Nephrol 2012;7:765-774.

179. Karaboyas A, Zee J, Brunelli SM, Usvyat LA, Weiner DE, Maddux FW, Nissenson AR, Jadoul M, Locatelli F, Winkelmayer WC, Port FK, Robinson BM, Tentori F. Dialysate potassium, serum potassium, mortality, and arrhythmia events in hemodialysis: results from the Dialysis Outcomes and Practice Patterns Study (DOPPS). Am J Kidney Dis 2017;69:266-277.

180. Heguilen RM, Sciurano C, Bellusci AD, Fried P, Mittelman G, Rosa Diez G, Bernasconi AR. The faster potassium-lowering effect of high dialysate bicarbonate concentrations in chronic haemodialysis patients. Nephrol Dial Transplant 2005;20:591-597.

181. Saran R, Bragg-Gresham JL, Levin NW, Twardowski ZJ, Wizemann V, Saito A, Kimata N, Gillespie BW, Combe C, Bommer J, Akiba T, Mapes DL, Young EW, Port FK. Longer treatment time and slower ultrafiltration in hemodialysis: associations with reduced mortality in the DOPPS. Kidney Int 2006;69:1222-1228.

182. Burton JO, Jefferies HJ, Selby NM, Mclntyre CW. Hemodialysis-induced repetitive myocardial injury results in global and segmental reduction in systolic cardiac function. Clin J Am Soc Nephrol 2009;4:1925-1931.

183. Cabrera C, Brunelli SM, Rosenbaum D, Anum E, Ramakrishnan K, Jensen DE, Stalhammar NO, Stefansson BV. A retrospective, longitudinal study estimating the association between interdialytic weight gain and cardiovascular events and death in hemodialysis patients. BMC Nephrol 2015;16:113.

184. Calkins H, Hindricks G, Cappato R, Kim Y-H, Saad EB, Aguinaga L, Akar JG, Badhwar V, Brugada J, Camm J, Chen P-S, Chen S-A, Chung MK, Cosedis Nielsen J, Curtis AB, Davies DW, Day JD, D'avila A, (Natasja) de Groot NMS, Di Biase L, Duytschaever M, Edgerton JR, Ellenbogen KA, Ellinor PT, Ernst S, Fenelon G, Gerstenfeld EP, Haines DE, Haissaguerre M, Helm RH, Hylek E, Jackman WM, Jalife J, Kalman JM, Kautzner J, Kottkamp H, Kuck KH, Kumagai K, Lee R, Lewalter T, Lindsay BD, Macle L, Mansour M, Marchlinski FE, Michaud GF, Nakagawa H, Natale A, Nattel S, Okumura K, Packer D, Pokushalov E, Reynolds MR, Sanders P, Scanavacca M, Schilling R, Tondo C, Tsao H-M, Verma A, Wilber DJ, Yamane T. 2017 HRS/EHRA/ECAS/APHRS/SOLAECE expert consensus statement on catheter and surgical ablation of atrial fibrillation. Europace 2018;20:e1. 